\title{
Organic Fouling in Forward Osmosis: A Comprehensive Review
}

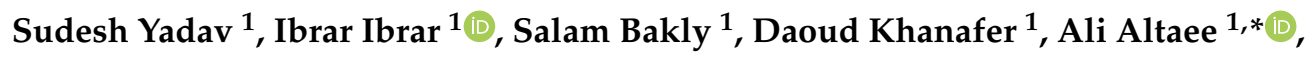 \\ V. C. Padmanaban ${ }^{2}$ D, Akshaya Kumar Samal ${ }^{3}$ and Alaa H. Hawari ${ }^{4}$ \\ 1 Centre for Green Technology, School of Civil and Environmental Engineering, \\ University of Technology Sydney, 15 Broadway, Sydney, NSW 2007, Australia; \\ sudesh.yadav@student.uts.edu.au (S.Y.); ibrar.ibrar@student.uts.edu.au (I.I.); \\ salam.bakly@student.uts.edu.au (S.B.); daoud.khanafer@student.uts.edu.au (D.K.) \\ 2 Centre for Research, Department of Biotechnology, Kamaraj College of Engineering and Technology, \\ Virudhunagar, Tamil Nadu 25701, India; vcpadmanaban88@gmail.com \\ 3 Centre for Nano and Material Science (CNMS), Jain University, Karnataka 562112, India; \\ s.akshaya@jainuniversity.ac.in \\ 4 Department of Civil and Architectural Engineering, College of Engineering, Qatar University, Doha 2713, \\ Qatar; a.hawari@qu.edu.qa \\ * Correspondence: ali.altaee@uts.edu.au
}

Received: 15 March 2020; Accepted: 21 May 2020; Published: 25 May 2020

\begin{abstract}
Organic fouling in the forward osmosis process is complex and influenced by different parameters in the forward osmosis such as type of feed and draw solution, operating conditions, and type of membrane. In this article, we reviewed organic fouling in the forward osmosis by focusing on wastewater treatment applications. Model organic foulants used in the forward osmosis literature were highlighted, which were followed by the characteristics of organic foulants when real wastewater was used as feed solution. The various physical and chemical cleaning protocols for the organic fouled membrane are also discussed. The study also highlighted the effective pre-treatment strategies that are effective in reducing the impact of organic fouling on the forward osmosis (FO) membrane. The efficiency of cleaning methods for the removal of organic fouling in the FO process was investigated, including recommendations on future cleaning technologies such as Ultraviolet and Ultrasound. Generally, a combination of physical and chemical cleaning is the best for restoring the water flux in the FO process.
\end{abstract}

Keywords: forward osmosis; membranes; organic fouling; FO membrane cleaning; wastewater treatment

\section{Introduction}

Water scarcity due to climate change and industrialization has urged researchers to focus on developing sustainable technology for desalination and wastewater purification [1,2]. Additionally, uncontrollable anthropogenic activities and an increase in population resulted in a huge rise of emerging pollutants in groundwater [2,3]. In general, wastewater contains a massive amount of pollutants including heavy metal ions, radioactive metals, pesticides, pharmaceutical waste, and many others [4]. A traditional pressure-driven membrane, such as microfiltration, ultrafiltration, nanofiltration, and reverse osmosis processes are applied to concentrate or purify a contaminated solution $[5,6]$. The pore size and pore distribution of the membrane in these processes decrease in the order of microfiltration $<$ ultrafiltration $<$ nanofiltration $<$ reverse osmosis [7]. With a decrease in pore size, the resistance of the membrane will increase for the mass transfer, which requires higher pressure to obtain the same flux $[6,8]$. The pollutants present in wastewater remain dissolved in water 
for a longer duration. Hence, the continuous operation for wastewater treatment is not feasible when using traditional pressure-driven membrane processes [9,10]. In addition, high energy consumption, the cost for chemical cleaning, and membrane life are other limitations for pressure-driven membrane processes [11].

Recently, researchers are attracted toward the potential of the forward osmosis (FO) technology for the water/wastewater treatment where a concentration difference between feed and draw solution acts as a driving force [12]. Lower energy consumption for water recovery makes FO one of the increasing separation technologies when compared with reverse osmosis. FO uses an osmotic pressure difference between concentrated draw solution and feed solution separated by a semi-permeable membrane to produce clean water [13]. The FO process has become popular due to high rejection of organics and micropollutants from wastewater [14]. The FO process works under the low-pressure condition when compared to traditional pressure-driven membrane processes (such as $\mathrm{RO}$ ), as shown in Figure 1.

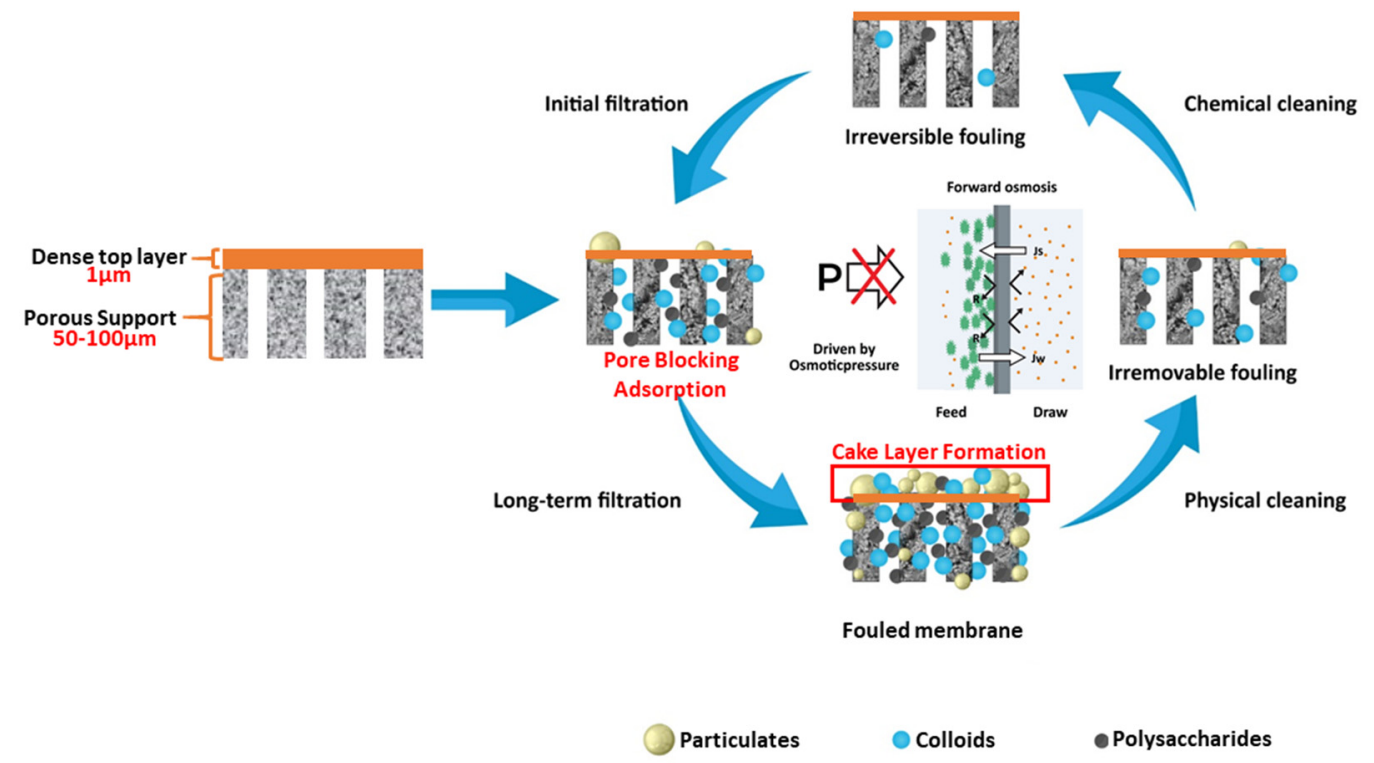

Figure 1. Schematic diagram of membrane fouling and cleaning mechanism in the forward osmosis (FO) processes.

Kessler et al. developed the concept of FO four decades ago, where both theoretical and experimental results were demonstrated to produce freshwater from saline water [15]. The FO process is applied for the osmotic dilution or the pre-treatment of seawater for hybrid FO-RO and multi-effect desalination plants $[16,17]$. Apart from desalination, currently, FO is utilized for the treatment of secondary or tertiary sewage effluent [18], landfill leachate water [19,20], and wastewater [21,22]. As mentioned above, since the energy consumption is low, zero liquid discharge systems make FO a sustainable technology for reclaiming wastewater treatment $[16,23]$. However, the production of concentrate needs to be addressed since wastewater treatment results in membrane fouling [13].

Fouling in the FO process can be mainly divided into biofouling, organic fouling, inorganic scaling, and colloidal fouling. Detailed information about the individual type of fouling is available in the literature [24,25]. Among these various types of fouling, organic fouling is perhaps the most complex and poorly understood [26]. Therefore, in this article, we attempt to review and focus on organic fouling in the FO process, particularly for wastewater treatment applications. We also highlight the characteristics of model organic foulants used in the FO literature and characteristics of organic foulants when the real wastewater is used as a feed solution. We explore and highlight recent advancements in membranes and nanomaterials for mitigation of organic fouling in the FO process. 


\section{Fundamentals of the FO Separation}

Forward osmosis uses an osmotic pressure gradient to permeate water from a solution of low solute concentration (also known as Feed solution or FS) through a semi-permeable membrane toward a solution of high solute concentration (also known as draw solution or DS). The draw solution generates the osmotic pressure required for freshwater extraction from the feed solution. FO uses the osmotic pressure difference $\Delta \pi$ rather than using hydraulic pressures $\Delta \mathrm{P}$ as in reverse osmosis [27]. The hydraulic pressure $\Delta \mathrm{P}$ is zero in the FO process [28], which negates the need for high-pressure hydraulic pumps and duplex stainless-steel tubing as required by reverse osmosis [29]. Due to the osmotic pressure gradient, water flows from the feed side to the draw side, and the draw solution becomes diluted. The FO process requires an additional process for freshwater separation from the draw solution.

The FO membrane is the heart of the FO system. FO membranes are asymmetric with a dense active layer and a porous support layer. In general, an asymmetric membrane having a polyamide layer on the top is utilized for the FO application [30]. Due to the nature of the structure of the FO membrane, internal concentration polarization (ICP) is the major drawback in FO, where feed contaminants deposit within the support layer. This results in a decrease of osmotic pressure and flux [31]. Hence, the structure of the support layer plays an important role in reducing ICP. A porous substrate with low resistance is recommended to achieve maximum performance in FO [32]. On the other hand, a selective thin polyamide (PA) layer is suggested for selectivity [33]. Asymmetric cellulose triacetate (CTA) membranes are known as first-generation FO membrane commercially supplied by Hydration Technology Innovations (HTI). A CTA material is used to prepare the dense active layer of this membrane, and a polyester mesh is used as a support layer. Low salt rejection, modest water flux, and limited $\mathrm{pH}$ tolerance were the main drawbacks of the CTA HTI membrane [34,35]. Afterward, Oasys Water and HTI supplied the second generation FO membranes named as thin-film composite (TFC), where the flux (30-40 LMH) has increased four times when compared to CTA [36]. Yet the rejection was almost equivalent to that of CTA. In the former case, the structural configuration can be altered accordingly, where microporous support material [37-40] can be changed to enhance permeability, and the selective PA layer can be tuned to cater to the end application. Usually, the support layer is fabricated using none solvent-induced phase separation and the selective layer of PA via interfacial polymerization (IP). Since 2015, more FO membrane suppliers have entered into the market such as the Trevi System, Modern water, Aquaporin A/S, etc. Hence, it is important to review the recent challenges and advancements in the development of FO membranes.

Polymeric membranes are commonly used in the industrial processes as supporting layers for FO membranes such as cellulose, cellulose triacetate [37], polysulfone (PSF) [38], polyethersulfone (PES) [39], and polyvinylidene fluoride (PVDF) [40]. Recently, ceramic and sintered metal-based membranes were also studied in industries [41]. The selection of membrane material must be made by keeping in mind the chemical and mechanical tolerances of membrane material toward foulants. Additionally, operational conditions and cleaning protocols are important for the selection of an appropriate membrane material. Yet, obtaining high hydrophilicity with excellent chemical and mechanical stability is still challenging. However, cellulose-based membranes showed a lower water contact angle, which helps in permeability with decreasing ICP, but poor resistance to hydrolysis and weak biological stability restrict its application. In the case of Polysulfone (PSF) $[38,42]$ and Polyethersulfone (PES) [39], the hydrophobicity restricts the water permeability. Additionally, high cost limits its application. Hence, it is important to fabricate an ideal membrane for FO, which has high permeability with good resistance to foulants. To solve this problem, various attempts have been made by incorporating different inorganic materials into the polymer matrix such as modified graphitic carbon nitride $\left(\mathrm{g}-\mathrm{C}_{3} \mathrm{~N}_{4}\right)$ [43], silica [44], $\mathrm{TiO}_{2}$ [45], zeolite [46], carbon nanotube [47] reduced graphene oxide (rGO) [48], and graphene oxide (GO) [49]. Recently, nanofiber-based membranes are also utilized for the $\mathrm{FO}$ processes [50]. Electrospinning and melt blowing techniques are used to incorporate nanofibers with carbon-based nanomaterials to develop a highly selective FO membrane. 
Electrospun nanofiber membranes (ENFMs) have connected porous framework with extensive pore size distributions, which enhanced its selectivity and permeability for wastewater treatment [51]. Pankaj M. Pardeshi et al. [52] introduced novel composite substrate material prepared using polyvinyl chloride and layered double hydroxide (LDH) for FO. An active layer facing feed solution (AL-FS) and an active layer facing draw solution (AL-DS) exhibited high pure water flux 37.46 LMH and 50.89 LMH, respectively, under osmotic flux evaluation [52].

The draw solution plays a pivotal role in the FO operation by providing the driving force for separation. In Forward Osmosis, water transport across a semi-permeable membrane is due to the osmotic pressure gradient between the draw solution side and the feed solution side [53]. The basic principle is that the osmotic pressure of the draw solution must be higher than the feed side to promote transport of water across the semi-permeable membrane [53,54]. Thus, an optimal draw solution is paramount for an efficient forward osmosis process. Most of the literature on the forward osmosis process revealed that finding an ideal solute that can easily be regenerated and reused is the main obstacle in the feasibility of an efficient forward osmosis process [55]. According to Johnson et al. [56], an effective draw solute must have high osmotic pressure, low viscosity, low reverse salt diffusion, high diffusion coefficient to mitigate ICP (internal concentration polarisation), must be non-toxic, must be available at low cost and high quantities, must be able to regenerate at a competitive cost, and must not contaminate the product water. However, there are some exceptions to this criterion. For instance, some draw solutes, such as $\mathrm{NaCl}$, have a small molecular size and high diffusion coefficients to mitigate internal concentration polarisation, but they exhibit high reverse salt flux. There is also not a unanimous agreement with whether a high diffusion coefficient will lead to low internal concentration polarisation [55] whereas several other researchers have used high viscosity hydrogels as draw solutions [57]. Furthermore, the regeneration step is void in cases where the end product is not freshwater such as when fertilizers are used as draw solution. The diluted fertilizers can be used for irrigation purposes or when industrial wastes are used as draw solutions [58,59].

The applications of FO in various applications are listed below.

I. The biggest advantage of FO in treating wastewater is its low fouling propensity. Wastewater has low osmotic pressure than seawater but has higher fouling propensity. Therefore, FO is ideal for treating complex wastewaters [60].

II. Recently, a study successfully adapted FO to concentrate radioactive liquid waste generated in hospitals. FO successfully rejected natural and radioactive iodine at a rate of $99.85 \%$, which is higher than $99.7 \%$ for Ultrafiltration (UF) and Reverse osmosis (RO) reported in the literature [61].

III. An integrated forward osmosis system can treat dewatered construction water (DCW) for reuse or for discharging into the sea, which reduces the adverse impacts of DCW on the environment if discharged to the sea directly [62].

IV. FO can be used to dewater textile wastewater and Brackish water [63], can reject oil from oily wastewater by up to $99 \%$ [64], and, under optimal conditions, can retain a high percentage of radioactive Cesium Cs(I) from simulated radioactive wastewater [65].

V. FO combined with electrochemical oxidation can reject more than $98 \%$ of antibiotics from pharmaceutical wastewater [66].

\section{Organic Fouling in the FO Process}

Effluent organic matter (EOM) and raw wastewater organic matter (WOM) such as proteins, cell debris (particulates), lipids, amino acids, antifoams, nucleic acids, polysaccharides (gums), colloidal particles, bovine serum albumin, alginate, humic, and folic acids are responsible for the membrane fouling in treatment of raw wastewater and wastewater effluent [59,67]. Organic fouling is brought about by amassing organic material such as proteins, sugar, humic, and polysaccharides. In wastewater, proteins tend to interact with each other via hydrogen bonding, which results in the aggregation on 
the membrane surface and further results in severe fouling [68]. Usually, the membrane fouling occurs due to pore blocking or solute aggregation caused by foulants. This process further results in the cake formation or gel layer on the membrane surface (Figure 1). Initially, the membrane fouling starts with the surface conditioning and then due to the chemical interactions between the active layer and foulants. There will be a change in the membrane structure over time. Additionally, it is a well-known fact that, with an increase in the surface roughness of the membrane, organic fouling caused due to Effluent organic matter (EOM) and raw wastewater organic matter (WOM) increases due to an increased interaction with the membrane surface $[56,69,70]$.

\subsection{The Adsorption Model for Predicting Permeate Flux Decline in the FO Process Due to Organics}

The resistance in the series model is generally used to describe flux decline due to the fouling process [71]. For the FO process in the absence of hydraulic pressure, the water flux $\left(J_{w}\right)$ can be presented as Equation (1).

$$
J_{w}=\frac{-\Delta \pi}{\eta R_{\text {total }}}
$$

where $\Delta \pi$ is the osmotic driving force for the FO process and $\eta$ is the viscosity of the solution. Rtotal represents the intrinsic resistance of the membrane to pure water, $R_{m}$, and every additional resistance such as adsorption resistance, $R_{a}$, concentration polarization layer resistance, $R_{c p}$, cake layer resistance, $R_{c}$, resistance due to pore-clogging, $R_{p}$, and resistance due to the gel-layer, $R_{g}$ [72]. Mathematically, $R_{\text {total }}$ can be presented by Equation (2).

$$
R_{\text {total }}=R_{m}+R_{c}+R_{c p}+R_{a}+R_{g}
$$

The pure water permeability " $A$ " value of the FO membrane using the resistance in series model can be obtained by Equation (3).

$$
A=\frac{1}{\eta R_{\text {total }}}
$$

Assuming that only fouling adsorption on the membrane surface is responsible for the increase in resistance. Equation (3) can be modified by the equation below.

$$
A=\frac{1}{\eta\left(R_{m}+R_{a}\right)}
$$

The increase in resistance due to adsorption of organics for the FO membrane can be, therefore, determined using Equation (4), if the pure water permeability $A$ value, the viscosity of the solution, and the resistance of the membrane to DI water is known.

Several studies have also demonstrated that the membrane fouling during filtration of wastewater containing organics is mainly due to the adsorption of organic compounds on the membrane surface $[73,74]$. At the initial stage of filtration, the fouling rate $(r)$ is related to the number of occupied sites $(\theta)$ by an organic compound (i) as presented by Equation (5) [75].

$$
r=\sum_{i} k_{i} \theta_{i}
$$

where $k_{i}$ is the fouling rate constant and $\theta$ is the surface coverage of the membrane by the organic compound. If we assume that the organic compounds are uniformly adsorbed on the membrane surface, the model can be presented by Equation (6) using the Langmuir model.

$$
\theta=\frac{K C_{m}}{1+K C_{m}}
$$


where $K$ is the Langmuir adsorption coefficient and $C_{m}$ is the concentration of organics on the membrane surface. The value of the denominator approaches the value of 1 for dilute solutions [75] and, therefore, Equation (6) can be presented as Equation (7).

$$
\theta=K C_{m}
$$

The adsorption of organics on the membrane surface is linearly proportional to the flux decline $\left(J_{0}-J\right)$.

$$
J_{0}-J=k_{a}\left(C_{m 0}-C_{m}\right) V
$$

where $J_{0}$ is the initial permeate flux, and $J$ is the water flux at time $t, k_{a}$ is the proportionality coefficient, and $V$ is the volume of the effluent. From Equation (8), the value of $\mathrm{Cm}$ can be expressed by the equation below.

$$
C_{m}=C_{m 0}-\frac{J_{0}-J}{k_{a} V}
$$

Substituting the value of $C_{m}$ into Equation (7), the surface coverage of the membrane by organics can be expressed by Equation (10).

$$
\theta=K C_{m}=K\left(C_{m 0}-\frac{J_{0}-J}{k_{a} V}\right)
$$

Substituting the value of $\theta$ in Equation (4), the fouling rate $r$ of the membrane by organics can be expressed by Equation (11).

$$
r=\frac{d J}{d t}=k \theta=k K\left(C_{m 0}-\frac{J_{0}-J}{k_{a} V}\right)
$$

Integrating Equation (11), at boundary conditions $t=0, J=J_{0}$ and re-arranging leads to Equation (12).

$$
J=J_{0}+k_{a} V C_{m 0}\left(e^{\frac{k K}{k_{a} V} t}-1\right)
$$

where the value of $k_{a} V$ can be obtained from the slope of Equation (8). The Langmuir coefficient $K$ can be determined from the Langmuir isotherm, and the value of $k$ can be obtained from the slope of Equation (11). Thus, the permeate flux decline due to the adsorption of organics on the FO membrane can be estimated from Equation (12). The value can be obtained by using one of the concentration polarisation models outlined by McCutcheon and Elimelech [76] and Yip et al. [77].

\subsection{Characteristics of Organic Foulants}

Natural organic matter (NOM) found in most ground and surface water is a complex mixture composed of humic acids, fulvic acids, low molecular weight organic acids, proteins, carbohydrates, and other compounds [78]. Frimmel et al. [79] divide natural organic matter (NOM) into two major classes. The first class, known as the autochthonous class, is derived from extracellular macromolecules of micro-organisms in the water body and carbon fixation by algae and aquatic plants [80]. In the second class of organic matter, which is known as allochthones, NOM is derived from the decay of plants and animal residues [79]. This type of NOM is also referred to as humic substances. The humic substances are further divided into humic and fulvic acid [78]. Humic acids are the high molecular weight fractions that are not soluble in water under acidic conditions (below $\mathrm{pH}$ 2), but become soluble at a high $\mathrm{pH}$ whereas fulvic acids are moderate molecular weight fractions soluble in water under all $\mathrm{pH}$ conditions [81]. However, researchers should think of humic acids as a substance rather than a molecule with a specific molecular weight [82].

Forward osmosis was proposed for treating feed waters with high organic content such as landfill leachate, oil and gas wastewater, shale gas wastewater, textile wastewater, and industrial wastewater [83-87]. However, the performance of the FO process is severely hindered by membrane fouling, particularly by organic foulants in the raw wastewater or wastewater effluent [88]. 
The deposition of organic foulants on a membrane surface is best depicted by the classical cake filtration model [75]. In the first stage, the organic foulants are deposited on the membrane surface, which leads to an increase in hydrophobicity of the membrane and reduced area for filtration. Subsequent deposition of organics on the membrane surface creates a fouling layer leading to a further increase in hydrophobicity and hydraulic resistance of the membrane [75]. The fouling in the FO is more exacerbated due to the reverse salt flux from the draw side since the salt is trapped in the fouling layer [89]. Once the fouling layer forms, a rapid flux decline is observed, and changes in hydrodynamic conditions or intermolecular adhesions have none or little effect on flux decline [90]. Under severe fouling conditions, fouling is governed by the interaction between the foulant approaching the membrane surface and the fouling layer [91,92].

Extensive research has been conducted to identify organic compounds responsible for membrane fouling and understanding the fouling mechanism [93]. Nevertheless, among the different types of fouling, organic fouling is perhaps the most poorly understood when compared to other types of fouling, such as biofouling and colloidal fouling [26]. The reason for this is mainly because the classification of organic fouling overlaps colloidal fouling (organic colloids) and biofouling (organic matter derived from microbial-cellular debris) [26]. Fouling of organic colloids is promoted mainly by divalent cations (calcium or magnesium), high initial flux, and hydrodynamic conditions such as low crossflow velocity [94]. Divalent cations, in particular, accelerate fouling of membranes by bridging humic acid molecules [90,95]. One study has demonstrated that humic acids have a high intermolecular interaction with divalent magnesium ions as compared to alginate [96]. The bridging effect of divalent cations with organic matter leads to a compacted fouling layer that leads to a severe flux decline [97]. A high permeate flux and low crossflow velocity lead to an increase in the concentration of divalent cations on the membrane surface due to concentration polarization, which, in turn, enhance membrane fouling [98]. An increase in crossflow velocity can mitigate the adverse effects of divalent cations binding to the organic matter on the membrane surface by reducing the concentration of the cations on the membrane. Lower permeate flux, on the other hand, is independent of calcium ion concentration [98].

\subsection{Model Organic Foulants Used in the Forward Osmosis Process}

Model organic foulants such as sodium alginate, bovine serum albumin, tannic acid, and humic acid are often used to simulate and investigate organic fouling of the FO membrane. Chemical structures of the model mentioned prior to foulants are shown in Figure 2. These model foulants were reported to be the major components of organic fouling in seawater and wastewater [99].<smiles>[NH3+]OC(=O)C1OC(O)C(O)C(O)C1O</smiles><smiles></smiles>
molecule

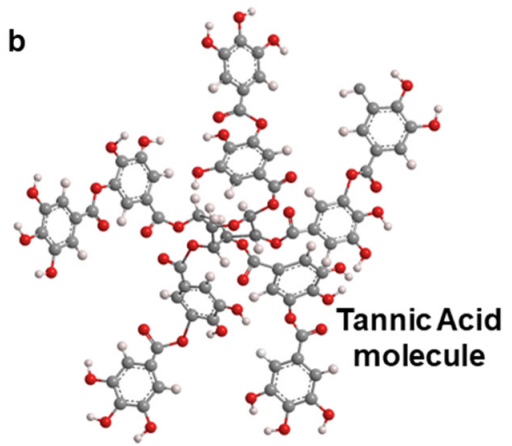

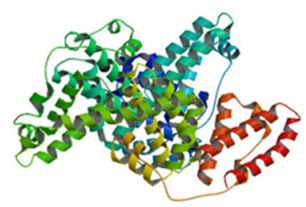

Bovine Serum albumin molecule

Figure 2. Molecular structure of model foulants. (a) Sodium alginate and Bovine serum albumin (BSA) adapted from Reference [100] and (b) tannic acid adapted from Reference [101]. (c) Humic acid. 
A wealth of literature has been published on the organic fouling investigation using model organic foulants. Simulated organic foulants, unfortunately, are not representative of the actual organic matter in real wastewaters and, hence, the results from such studies would not resemble the situation of membrane fouling in the real wastewater environment or pilot plant. The chemical structure of the model organic foulant might be significantly different from the foulant in real wastewater [93]. Properties of model organic foulants are summarized in Table 1. Practically, there is a wide range of organic substances in the real wastewater responsible for membrane fouling. Thus, laboratory results using model organic foulants are not entirely reliable [102]. However, the use of model foulants still allows researchers to understand the fundamentals of the fouling mechanism under constant and well-defined conditions [93].

Table 1. Properties of model foulants.

\begin{tabular}{|c|c|c|c|c|}
\hline Type of Fouling & Model Foulant & Molecular Weight ** & Properties & Reference \\
\hline Organic & Sodium Alginate & $216.12 \mathrm{~g} / \mathrm{mol}$ & $\begin{array}{l}\text { Represents polysaccharides. } \\
\text { Carboxylic groups are } \\
\text { protonated under neutral pH. } \\
\text { The molecular structure is not } \\
\text { sensitive to photo excitation. }\end{array}$ & [103-105] \\
\hline Organic & $\begin{array}{l}\text { Bovine Serum } \\
\text { Albumin (BSA), } \\
\text { Humic Acid, } \\
\text { Sodium Alginate }\end{array}$ & $\begin{array}{c}66430.3 \mathrm{~g} / \mathrm{mol} 227.17 \\
\mathrm{~g} / \mathrm{mol}\end{array}$ & $\begin{array}{l}\text { BSA represents proteins, while } \\
\text { humic acid represents humic } \\
\text { matter. }\end{array}$ & [90] \\
\hline Organic & $\begin{array}{l}\text { Alginate, humic } \\
\text { acid, and BSA }\end{array}$ & - & $\begin{array}{l}\text { Carboxylic acidities are } 3.5,3.4, \\
\text { and } 1.0 \mathrm{meq} / \mathrm{g} \text {, respectively, for } \\
\text { the three foulants. }\end{array}$ & {$[99,105]$} \\
\hline Organic & Humic Acid salt & - & $\begin{array}{c}\text { Carboxylic groups are } \\
\text { protonated under neutral } \mathrm{pH} \\
\text { conditions. }\end{array}$ & {$[105,106]$} \\
\hline Organic & Tannic acid & $1701.19 \mathrm{~g} / \mathrm{mol}$ & $\begin{array}{l}\text { High tannic acid in feed solution } \\
\text { affects FO membrane retention. } \\
\text { Enhances internal concentration } \\
\text { polarisation by penetrating the } \\
\text { porous layer. }\end{array}$ & {$[96,107]$} \\
\hline Organic & Indole & $117.15 \mathrm{~g} / \mathrm{mol}$ & $\begin{array}{l}\text { Nitrogen-containing } \\
\text { heterocyclic agent found in } \\
\text { coking wastewater. }\end{array}$ & [108] \\
\hline Organic & Pyridine & $79.1 \mathrm{~g} / \mathrm{mol}$ & $\begin{array}{l}\text { Mostly found in coking } \\
\text { wastewater. Endocrine } \\
\text { disruptor. }\end{array}$ & [108] \\
\hline
\end{tabular}

${ }^{* *}$ Molecular weights from Pubchem.

Lee et al. [99] used alginate, Suwanee river humic acid, and Bovine Serum Albumin (BSA) as model foulants to investigate organic fouling in the FO. RO experiments were conducted in parallel for comparison of fouling behaviour between the $\mathrm{FO}$ and the RO process. This study also investigated the impact of draw solutions on the FO fouling. Hence, two different types of draw solutions ( $\mathrm{NaCl}$ and dextrose) were used. Experimental results showed that the structure of the fouling layer is affected by both physical (initial flux, cross-flow velocity, and pressure) and chemical ( $\mathrm{pH}$, ionic strength, and presence of divalent cations) conditions. Similar results were obtained by another study using model organic foulants [90]. For solutions with a lower reverse salt flux such as dextrose, cake enhanced osmotic pressure (CEOP) is less severe when compared to solutions with a high reverse salt flux such as $\mathrm{NaCl}$ [99]. According to the Lee et al. study, the permeate flux decline due to BSA was less than the permeate flux decline due to alginate or humic acid due to Hofmeister effects for protein for the BSA [109]. The decline in water flux may also occur due to the cake layer formation under the hydrodynamic conditions. BSA will only form a cake layer when the hydrodynamic conditions are 
most favourable, whereas alginate forms a cake layer under all hydrodynamic conditions due to its strong molecular adhesion [90].

Several researchers have suggested that the effect of mixtures of model foulants is different from the sum of individual effects [110,111]. As such, for simulated fouling conditions, a mixture of foulants would be more suitable to simulate real wastewater like the environment for fouling studies. Wang et al. [96] systematically investigated the effects of combined organic foulants (tannic acid and alginate) in the FO process in the Active layer-Draw Solution (AL-DS) or Pressure retarded osmosis (PRO) mode (active layer facing draw solution). Experiments demonstrated that tannic acid plays a significant role in flux decline and fouling compared to alginate, and the presence of divalent calcium ions had a favourable effect on flux decline by combined foulants. Another study by Balkenov et al. [112] showed that, when two model foulants (alginate + BSA or tannic acid) were added to a feed solution, there was a $12 \%$ loss in permeate flux. However, when three foulants were added to the feed side, the flux declined by $27 \%$. This study also concluded that water flux declined by individual foulants could not be an indicator of water flux reduced by combined foulants. Similar results were reported for combined colloidal and organic fouling using model foulants, where synergetic effects were observed for combined foulants [113].

\subsection{Characteristics of Organic Foulants in Real Wastewater}

Parida and $\mathrm{Ng}$ [102] systematically investigated organic fouling in the forward osmosis using RO brine instead of model organic foulants. The draw solution used in this study was $2 \mathrm{M} \mathrm{NaCl}$. The analysis of the organic foulants on the membrane structure revealed that organic foulants possess an irregular and random structure, whereas inorganic salts have a well-defined crystalline structure. Binding mechanism of calcium with humic acid is shown in Figure 3. The structure of the organic fouling layer is mainly affected by solution chemical conditions (such as $\mathrm{pH}$, ionic strength, and presence of divalent cations) as well as by initial flux, cross-flow velocity, and pressure [99].

a<smiles>Cc1c(C(=O)O)c(O)c(C(=O)O)c(O)c1C(C(=O)O)C(O)C(C)c1c(C(=O)O)c(O)c(CC(=O)C(CC(=O)O)C(=O)O)c(O)c1C(=O)O</smiles>

b

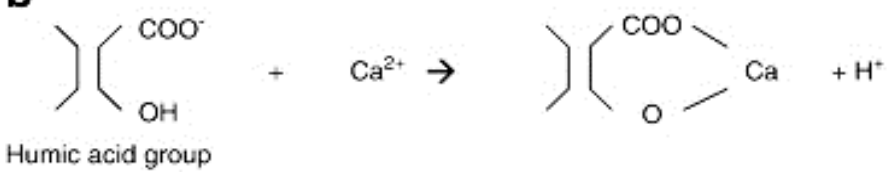

Figure 3. Structure of Humic acid (a) Binding of calcium with the humic acid group (b) adapted from Reference [102].

Table 2 lists different studies and their main findings for organic fouling in the FO process using real wastewater feed solutions. Pramanik et al. [114] investigated organic fouling in the FO process using municipal wastewater as a feed solution and $\mathrm{NaCl}$ as a draw solution. The Thin-film composite (TFC) Porifera membrane was used in this study. The TFC FO membrane achieved a rejection rate of almost $100 \%$ for fluorescent molecules indicating these molecules also play a significant role in FO membrane fouling. Pramanik et al. [114] also concluded that fouling due to organic matters of large size molecular weight is reversible, whereas small molecular weight organics promote irreversible fouling and are stubborn to remove. Dong et al. [20] investigated the treatment of landfill leachate with a forward osmosis process using the HTI membrane and $3 \mathrm{M} \mathrm{NaCl}$ draw solution. This study 
also found that proteins and polysaccharides were the major organic foulants on the membrane. The organic fouling layer on the membrane also hindered the back diffusion of salt from the draw solution, which led to inorganic precipitation.

Table 2. Different studies and their main findings for organic fouling in the forward osmosis (FO) process.

\begin{tabular}{|c|c|c|c|c|}
\hline Type of Wastewater & Membrane Used & Draw Solution & Major Findings & Ref. \\
\hline $\begin{array}{l}\text { Municipal } \\
\text { wastewater }\end{array}$ & $\begin{array}{l}\text { Thin-film } \\
\text { composite (TFC) } \\
\text { Porifera }\end{array}$ & $\begin{array}{l}1 \text { M Sodium } \\
\text { chloride }(\mathrm{NaCl})\end{array}$ & $\begin{array}{c}\text { Larger molecular organics contribute } \\
\text { more to reversible fouling, whereas } \\
\text { low molecular organic promotes } \\
\text { irreversible fouling. }\end{array}$ & [114] \\
\hline $\begin{array}{l}\text { Biologically treated } \\
\text { landfill leachate }\end{array}$ & $\begin{array}{l}\text { Cellulose triacetate } \\
\text { (CTA) HTI }\end{array}$ & $3 \mathrm{M} \mathrm{NaCl}$ & $\begin{array}{l}\text { Protein and polysaccharides are major } \\
\text { organic foulants in the landfill } \\
\text { leachate. }\end{array}$ & [20] \\
\hline Landfill leachate & $\begin{array}{c}\text { CTA Fluid } \\
\text { Technology } \\
\text { Solution (FTS) }\end{array}$ & $5 \mathrm{M} \mathrm{NaCl}$ & $\begin{array}{l}\text { Low molecular weight organics have } \\
\text { more pore-penetrating ability and } \\
\text { strong binding with the membrane } \\
\text { surface. }\end{array}$ & [115] \\
\hline Dairy wastewater & TFC Porifera & $1 \mathrm{M} \mathrm{NaCl}$ & $\begin{array}{l}\text { No passage of building blocks, low } \\
\text { molecular weight organics, and } \\
\text { humic substances through the FO } \\
\text { membrane, and these are responsible } \\
\text { for organic fouling. }\end{array}$ & [116] \\
\hline $\begin{array}{c}\text { Secondary } \\
\text { wastewater effluent }\end{array}$ & $\begin{array}{l}\text { CTA Hydration } \\
\text { Technology } \\
\text { Innovations (HTI) }\end{array}$ & $0.5 \mathrm{M} \mathrm{NaCl}$ & $\begin{array}{l}\text { Hydrophilic high molecular weight } \\
\text { organics are the initial foulants on the } \\
\text { FO membrane. }\end{array}$ & [117] \\
\hline $\begin{array}{l}\text { Waste activated } \\
\text { sludge }\end{array}$ & $\begin{array}{c}\text { TFC (Toray } \\
\text { chemicals, Korea) }\end{array}$ & Synthetic seawater & $\begin{array}{l}\text { Organic and inorganic compounds } \\
\text { promoted fouling on the membrane. }\end{array}$ & [118] \\
\hline $\begin{array}{l}\text { Microalgae } \\
\text { wastewater }\end{array}$ & TFC Porifera & $\begin{array}{l}2 \mathrm{M} \text { Magnesium } \\
\text { chloride }\left(\mathrm{MgCl}_{2}\right)\end{array}$ & $\begin{array}{l}\text { Microalgae cells and algogenic } \\
\text { organic matter was mainly } \\
\text { responsible for fouling on the FO } \\
\text { membrane. }\end{array}$ & [119] \\
\hline $\begin{array}{l}\text { Soluble algal } \\
\text { products wastewater }\end{array}$ & $\begin{array}{l}\text { CTA HTI and TFC } \\
\text { (lab-fabricated) }\end{array}$ & $\begin{array}{l}1 \mathrm{M} \mathrm{NaCl} \text {, Calcium } \\
\text { chloride }\left(\mathrm{CaCl}_{2}\right) \\
\text { and } \mathrm{MgCl}_{2}\end{array}$ & $\begin{array}{l}\text { Fouling was more severe with } \mathrm{CaCl}_{2} \\
\text { as the draw solution. The adsorption } \\
\text { of algal products was higher for the } \\
\text { TFC membrane than the CTA } \\
\text { membrane. }\end{array}$ & [34] \\
\hline
\end{tabular}

Another study reported that low molecular weight organic foulants penetrate the pore of the membrane surface more easily than high molecular weight organics in a landfill leachate wastewater using CTA membrane and $5 \mathrm{M} \mathrm{NaCl}$ draw solution [115]. This study also reported that low molecular weight organics have a strong binding with the CTA membrane than high molecular ones. However, building blocks and humic-like substances contributed more than the low molecular organic foulants to the irreversible fouling on the TFC Porifera membrane used for treating dairy wastewater [116]. Furthermore, it was found that the initial foulants on the membrane surface were high molecular weight organics when secondary wastewater effluent was used as a feed solution for a CTA membrane and $0.5 \mathrm{M} \mathrm{NaCl}$ draw solution [117]. It is clear from the results of different studies that the fouling behaviour changes with the membrane type and feed solution type [118,119]. As such, the different types of wastewater results in different fouling mechanisms. The CTA membrane shows more resistance to organic fouling than the commercial TFC membrane in both the FO and the Pressure retarded osmosis (PRO) mode [104]. For this reason, the majority of the studies in the FO literature use the CTA membrane for wastewater treatment applications [120,121] and are compared to TFC membranes. Some studies have reported excellent antifouling behaviour (for model organic foulants) for laboratory fabricated TFC membranes known as thin-film nanocomposite membranes [122]. 
However, the performance of these membranes with real wastewater feed solution are scarce in the FO literature and might need further investigation.

Few studies have investigated draw solutions other than $\mathrm{NaCl}$ for wastewater treatment. Ye et al. [119] investigated the dewatering of algal wastewater using a TFC Porifera membrane and $\mathrm{MgCl}_{2}$ draw solution. The initial water flux at $4 \mathrm{M}$ draw solution was lower than that at $3 \mathrm{M}$ draw solution in the first $30 \mathrm{~min}$ due to the higher initial flux at higher draw solution concentration, which created a higher permeation drag and higher deposition of foulants. Microalgal cells and algogenic organic matter (AOM) was mainly responsible for fouling in the treatment of algal wastewater. Li et al. [34] investigated three different draw solutions $\left(\mathrm{NaCl}, \mathrm{CaCl}_{2}\right.$, and $\left.\mathrm{MgCl}_{2}\right)$ and two different membranes (CTA HTI and TFC lab-fabricated) for dewatering of soluble algal products wastewater. The higher flux decline was achieved with $\mathrm{CaCl}_{2}$ draw solution for both membranes. When $\mathrm{MgCl}_{2}$ was used as draw solution, the flux loss in the CTA membrane was higher than the TFC membrane in the PRO mode. The adsorption of algal products on the CTA membrane surface was lower than the TFC membrane in the membrane orientation. The adsorption of algal products was also dependent on the reverse salt flux of the draw solution. A higher reverse salt flux increased the adsorption of algal products on the membrane surface. The impact of different draw solutions on organic fouling behaviour with different feed solutions is scarce in the literature, and further research is needed in this area.

Organic fouling with real wastewater feeds is also significantly influenced by inorganic matter. A recent study by Im et al. [117] revealed that organic compounds ( $\mathrm{C}$ and $\mathrm{O}$ ) and inorganic ions ( $\mathrm{Ca}$ and $\mathrm{Fe}$ ) interact with each other on the membrane surface to form a fouling layer with a more complex structure. The reason for this is due to the adsorption of organic macromolecules onto a membrane surface, which creates a conditioning layer serving as a platform for inorganic scaling of FO membranes [123]. Similar results were reported for treating activated sludge with the TFC (Toray chemicals) membrane using synthetic seawater draw solution [118]. The inorganic foulants (Fe and $\mathrm{P}$ ) on the fouling layer were from the feed solution since they were not present in the synthetic seawater draw solution.

\section{Organic Fouling Mitigation with Pre-Treatment}

Pre-treatment reduces membrane fouling either by removing or modifying the foulants in wastewater [124]. Cost-effective pre-treatment of wastewater can have numerous benefits such as disinfection, settling of large suspended particles, and removal of total suspended solids (TSS) as well as low fouling propensity of the feed wastewater after pre-treatment. Pre-treatment of wastewater includes but is not limited to using sand filters, settling and multimedia filters [62], and using Ultrasound and Ultraviolent (UV) treatment [125] coagulation-flocculation and flotation [126]. Employing cost-effective pre-treatment for high Total dissolved solids (TDS) solution can help reduce membrane fouling, protect the membrane, and improve Forward osmosis (FO) performance [127]. Settling and multimedia filtration has been proven as an excellent alternative for dilution of seawater in a hybrid FO system [62]. In the settling process, the settleable solids tend to settle down at the bottom due to a gravitational sedimentation mechanism. The settling method was able to enhance the flux by $13.5 \%$, and multimedia filtration removed most of the particles that would induce fouling (Figure 4). However, settling cannot remove the small particulate matter in the feed water, which is the leading cause of membrane fouling in the FO process.

Urea hydrolysis, in combination with a low $\mathrm{pH}$ feed solution, can significantly improve the total nitrogen (TN) rejection in aquaporin-based membranes in the FO process [128]. The results in the referenced study revealed that this pre-treatment could increase the TN rejection from $67 \%$ to $89 \%$ at a water recovery rate of $75 \%$ using a $5 \mathrm{M} \mathrm{NaCl}$ draw solution. This process, however, consumes a great amount of $\mathrm{HCl}$ for lowering the feed solution $\mathrm{pH}$ and is not suitable for practical applications. Electro-coagulation pre-treatment can also be an effective option for produced water treatment and has been proven to achieve a total organic carbon (TOC) rejection of up to $91.3 \%$ and $99 \%$ for Total 
suspended solids (TSS) [129]. An alternative to these approaches, granular activated carbon (GAC) is considered to be one of the best adsorbents for the removal of TOC. GAC pre-treatment in combination with the FO process restricted almost all the organic pollutants from a reverse osmosis concentrate feed solution to a $2 \mathrm{M} \mathrm{NaCl}$ draw solution [130].

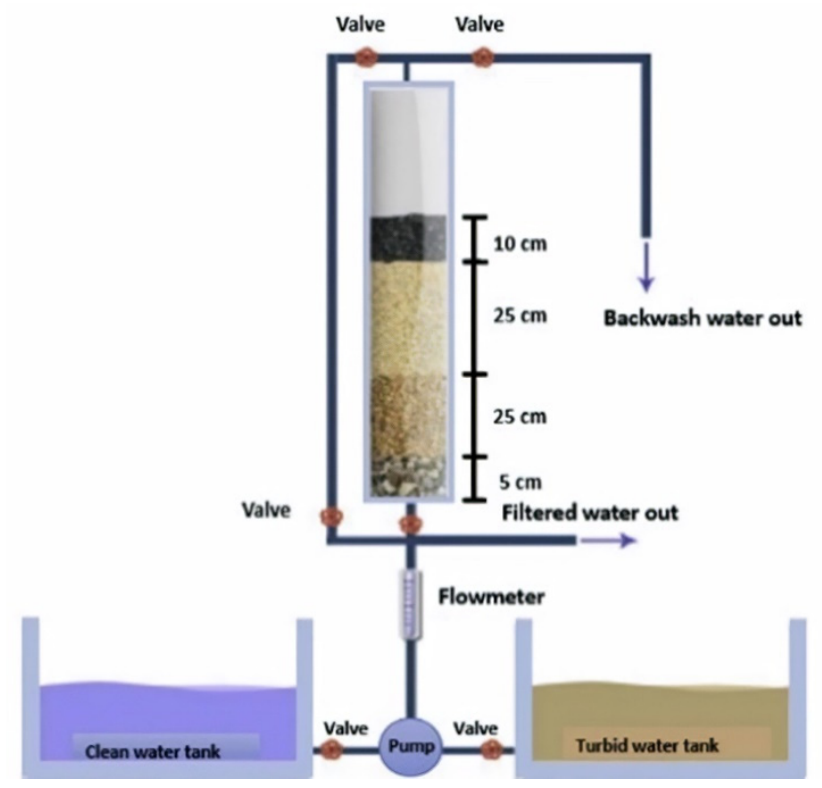

Figure 4. Multimedia sand filter unit for the pre-treatment of construction wastewater [62].

\section{Cleaning Protocols for Fouled FO Membranes}

During the FO process, the membrane surface gets fouled, which causes a decline in the permeability and selectivity of the membrane. Several cleaning methods were suggested and developed by researchers to restore the membrane water flux. However, the cleaning protocols should not damage the membrane and must be practical and less time consuming with an ease of installation. Moreover, the cleaning solutions and cleaning cycles are one of the critical factors to decide the membrane life.

\subsection{Physical Cleaning}

The initial step in the physical cleaning involves the unwinding and redissolution of the foulant layer into the feed stream. Direct flushing at high cross-flow velocity is applied to remove firmly attached foulants. Loosely bounded foulants can be easily removed by flushing the membrane module with water. For plate and flat sheet modules, backflushing can be applied to reduce the fouling within pores and to eliminate the cake layer or gel layer formation on the active site of the membrane. In contrast, the non-homogeneous flow through the pores restricts its applicability. Recently, researchers reported the energy cost and an ultra-sonication cleaning to remove foulants, but the main challenges are scaling up. Air scouring is utilized as a cleaning strategy to control the membrane fouling effect and to prevent any complicated reaction before it occurred [131].

The cake layer formed in the $\mathrm{FO}$ and $\mathrm{RO}$ processes is very different. Compressible foulants in $\mathrm{RO}$ formed a dense cake layer, which can reduce flux and increase the energy due to increasing the hydraulic resistance along the membrane. On the other hand, the flux decline in the FO was due to cake formation on the membrane surface because of the enhanced osmotic pressure [99]. The fouling in FO was reversible and not compressed when compared to the RO mode, which involved the hydraulic pressure, and may affect the morphology of the alginate gel. As a result, cleaning the FO membrane was easier than the RO mode due to lower hydraulic compaction of the foulant layer [103]. Many factors can affect the efficiency of membrane cleanings such as type of feed water, membrane type, duration frequency, and intensity [132]. Surface flushing is an effective method for cleaning the 
reversible foulant on the FO membrane surface. The membrane can simply obtain cleaning efficiency by around $98 \%$ with increased cross-flow velocity and cleaning duration. Additionally, air bubbles can be added to enhance the cleaning efficiency due to increasing shear force on the membrane and the turbulence, and reducing the time of cleaning. Hence, this may achieve $100 \%$ efficiency without any chemical reagents [133]. However, this method is insufficient for the RO membrane due to the porous factor of the support layer, which can decline the shear force and reduce the cleaning efficiency [134]. Osmotic backwashing is another physical cleaning method that can be used for the FO membrane. The osmotic backwash is implemented by reducing the salinity of the draw solution and increasing the feed solution salinity or swapping the feed with the draw solution inlet to break down the foulant on the support layer [135]. Some studies recommended osmotic backwash as an effective cleaning method, especially with membrane fouled by complex water such as anaerobic digester concentrate, MBR feed water, industrial wastewater, and municipal wastewater [136-140].

In contrast, other studies reported low flux recovery obtained when using osmotic backwashing for membrane cleaning [134,141]. Some foulants may form gypsum in the support layer and required additional hydraulic backwash to obtain $100 \%$ flux recovery, especially in the RO mode due to a compressed foulant. In case of using the cellulose acetate (CA) membrane for both FO and RO, apply $4 \mathrm{M} \mathrm{NaCl}$ Draw solution for FO and, under 28 bars, hydraulic pressure for RO for $20 \mathrm{~h}$ until the flux notably reduced. The cleaning process by rinsing the foulant membrane with $50 \mathrm{mM} \mathrm{NaCl}$ solution for $15 \mathrm{~min}$ found that the flux on the FO membrane recovered by around 100\%, while, for $\mathrm{RO}$, was around 70\% [103]. Therefore, osmotic backwashing can be used for the FO mode due to the lower compaction of foulant on the membrane while, in case of the $\mathrm{RO}$, the suitable method for physical cleaning is hydraulic backwashing in case of cleaning without chemical reagents.

\subsection{Chemical Cleaning}

Since complete removal of foulants is not possible, using physical cleaning, various chemicals are used to break down the chemical structure and bonding of foulants with the membrane. Chemicals used in cleaning reacts with foulants to enhance their solubility by the degradation of foulants in a more soluble form. Surfactants and wetting agents are also used as cleaning chemicals since they can easily remove the foulants inside the pore. The sanitization operation is performed to avoid the growth of microorganisms on the membrane surface. In some studies, hypochlorite is applied as a disinfectant agent. Mass transfer of foulants and chemicals to and from the membrane decides the efficiency of cleaning. Circulation time and flow rate at various $\mathrm{pH}$ of cleaning with chemicals is a critical factor in obtaining highly efficient cleaning. In general acids, bases, steam, gas sterilization, and sequestrants are used as cleaning agents. Acid solution mainly reduces efficiently inorganic fouling while the whole alkali solution is responsible for removing organic fouling [142].

Information about the main components of the water source and fouling composition helps to obtain better cleaning in a short amount of time while considering safety, cost, and the impact of the cleaning agent to the environment and membrane [143]. Gao, Liang et al., 2011, reported that sometimes two agents need to be mixed to reduce foulant from the surface of one membrane [131]. Tragardh (1989) stated that chemical cleaning should follow some steps to avoid damaging the system and sustainable working such as keeping the fouling loose and solute to avert forming new fouling and keep the membrane clean and safe with all other wetted surfaces sterilized. Additionally, the efficiency of the chemical cleaning depends on the flow rate of the cleaning, concentration, and temperature of cleaning material and the percentage of the foulant [144]. The positive effect of the interaction between the foulant and the chemical agent can be presented in three ways: (i) the foulant can be removed, (ii) the morphology of the foulant can be changed such as swelling or compacting, and (iii) the hydrophobic or charged is modified because the surface chemistry of the deposit may be altered [145]. This cleaning agent may react chemically with foulant so they can break down the cohesion force between the foulant ions and reduce the adhesion force between the foulants and the membrane surface. 
In the case of the FO membrane, thin-film composite (TFC) required chemical cleaning due to strong adhesion with alginate when compared to the cellulose triacetate (CTA) membrane [103]. Sodium hydroxide $(\mathrm{NaOH})$, sodium ethylenediaminetetraacetic acid (EDTA), and sodium hypochlorite $(\mathrm{NaOCl})$ with a concentration range between $0.5-1.0 \%$. Several studies reported that chemical cleaning could achieve highly efficient membrane cleaning from organic foulant, which may have a strong interaction to the membrane surface [136,146-149]. Although chemical cleaning has a high cleaning efficiency, hardly removed foulant from membrane pores [136], can be harmful to the FO membrane, may reduce the membrane life [141], and might cause an environmental problem due to the effluent stream during the cleaning process [103,150]. For an example of RO mode, cleaning reagents chosen for an organic foulant similar to $\mathrm{FO}$ as $\mathrm{NaOH}$ as an alkaline solution, certified grade disodium ethylenediaminetetraacetate (Na2-EDTA) as a metal chelating reagent, certified grade sodium dodecyl sulphate (SDS) as an anionic surfactant, and $\mathrm{NaCl}$ as a salt cleaning solution at $\mathrm{pH} 11$ [151]. Thin-film composite LFC-1 as an RO membrane was used, and the foulants within the irreversible fouling layer on the membrane surface, which may have a strong intermolecular adhesion force between particles from wastewater effluent [152]. The cleaning process starts by adding the chemical reagent as a feed solution for a suitable duration time, which may also affect the cleaning efficiency. Some flounts required one chemical cleaning reagent to obtain a high cleaning efficiency, while others need to combine more than one at the same time. Generally, Ang, Yip et al. (2011) stated that adding $\mathrm{NaOH}$ as a cleaning reagent (alone or combined with another reagent) can improve the cleaning performance due to its capability to loosen the fouling layer.

\subsection{Physio-Chemical Cleaning}

Some foulants cannot be effectively removed by physical cleaning only, so are required to combine a chemical cleaning process to recover membrane permeability [153]. This method utilizes physical cleaning methods gathering some chemical agents to improve the capability of the cleaning process. Some researchers use the backflush water method by adding a small amount of the chemical agent to the water. This procedure can enhance the cleaning efficiency [154]. This method keeps improving, and currently, they use a developed method for a mechanical-chemical cleaning process with ultra-sonication-enhanced chemical cleaning [155]. Adding low frequencies of the ultrasound to a chemical cleaning agent like ethylene diamine tetra-acetic acid (EDTA) will enhance the cleaning process more than using the chemical or ultrasound separately [156].

\subsection{Biological/Biochemical Cleaning}

A biological foulant can attach reversibly or irreversibly to the membrane surface due to the interaction between the biomass and the membrane surface. The interaction between colloidal particles and bacteria cells blocks the membrane pores. Some chemical compounds such as hydrogen peroxide $\left(\mathrm{H}_{2} \mathrm{O}_{2}\right)$ can harm the membrane and may cause fouling with a negative effect on the microbial community. If there is any bio-fouling formed on the membrane, using one of the biological cleaning methods with different chemical agents such as biocide solution can minimize the effect of the bio-fouling [157] or using mixtures of cleaning contains bioactive agents like enzymes or single molecules to promote the foulants extract [158]. Using an environmentally-friendly and mild cleaning agent like purified enzymes and surfactants to avoid damage or corrosion to the membrane surface during the biological cleaning process is advised [159]. For example, some researchers used a new enzymatic protocol for biological cleaning to UF fouled membrane used for abattoir effluent and obtain a $100 \%$ flux recovery [160]. Although two more strategies can be used to control osmotically-driven membrane processes (ODMPs), membrane fouling such as energy uncoupling and quorum quenching [161], enzymatic cleaning is the most common biological method for FO and RO membrane cleaning [154]. 


\subsection{Factors Influencing Cleaning Efficiency}

Many factors impact the cleaning efficiency of the fouled membrane, such as the sequence of the cleaning steps. Practically, physical cleaning can remove loose particles on the membrane surface (reversible fouling). Generally, physical cleaning cannot retrieve membrane permeability effectively, and a combination of chemical and physical cleanings are usually used for the removal of such fouling $[153,162]$. In addition, the sequence in the chemical cleaning may affect the membrane permeability degree. Some studies reported that an alkaline cleaning substance could be more efficient when followed by an acid cleaning substance better than when cleaning the membrane from dominant organic matter foulants $[163,164]$. Other studies found that precipitation of an inorganic scaling or metal hydroxide on the membrane surface prefers acid than the alkali substance sequence for the cleaning process $[142,165]$.

Temperature is considered another factor that may take effect on the membrane cleaning strategy. Increasing temperature is substantial for cleaning the fouling membrane by increasing solubility due to reactivity of functional groups at high temperatures of the organic matters and increasing mass transfer dispersive with mechanical destabilization of biofilm layers on the membrane surface [166]. In contrast, high-temperature biofilm tends to precipitate on the membrane surface in the form of calcium carbonate, ferric hydroxide, and silicates, which makes the process more difficult to separate [167].

Increasing the $\mathrm{pH}$ has a direct proportion with membrane cleaning efficiency in case all carboxylic functional groups of EDTA are deprotonated [168]. For instance, increasing $\mathrm{pH}$ from 4.9-11.0 will affect the cleaning percentage from $25 \%-44 \%$ and, at $\mathrm{pH} 11$, are very easy to break down the gel layer on the membrane surface when compared to the lower $\mathrm{pH}$. While Ang, Lee et al. (2006) found that, in the case of sodium dodecyl sulphate (SDS), the effect of the $\mathrm{pH}$ is very low on the cleaning efficiency because the chemical reaction between the foulants and the SDS effect slightly by changing $\mathrm{pH}$ [168]. Table 3 shows the cleaning protocols for fouled membranes. Furthermore, Al-Amoudi, A. concluded that permeable efficiency relies on the membrane cleaning step within the membrane process [164].

Table 3. Cleaning protocols for fouled forward osmosis (FO) membranes.

\begin{tabular}{|c|c|c|c|c|c|c|c|}
\hline $\begin{array}{l}\text { Cleaning } \\
\text { Method }\end{array}$ & $\begin{array}{l}\text { Membrane } \\
\text { Type }\end{array}$ & Feed Solution & $\begin{array}{c}\text { Draw } \\
\text { Solution }\end{array}$ & $\begin{array}{l}\text { Factors/Cleaning } \\
\text { Condition }\end{array}$ & $\begin{array}{c}\text { Cleaning } \\
\text { Efficiency \% }\end{array}$ & Flux $\%$ & Ref. \\
\hline \multirow[b]{2}{*}{ Mechanical } & $\begin{array}{l}\text { Vertical hollow } \\
\text { fibres }\end{array}$ & Bentonite & - & $\begin{array}{l}8 \mathrm{~mm} \text { amplitude }+8 \mathrm{~Hz} \\
\text { frequency vibration } \\
\text { compared to no vibration }\end{array}$ & 90 & - & [169] \\
\hline & $\gamma-\mathrm{Al}_{2} \mathrm{O}_{3}$ ceramic & $\begin{array}{l}\text { Natural water } \\
\text { include colloidal } \\
\text { silica }\end{array}$ & - & $\begin{array}{c}3.5 \mathrm{~cm} \\
2.6 \mathrm{~cm} \\
1.7 \mathrm{~cm} \\
\text { Distance between the } \\
\text { ultrasonic source probe } \\
\text { and the membrane } \\
\text { surface for } 1.56 \mu \mathrm{m} \\
\text { particles }\end{array}$ & 100 & $\begin{array}{l}60 \\
75 \\
97\end{array}$ & [170] \\
\hline \multirow[b]{2}{*}{ Chemical } & $\begin{array}{l}\text { Hydrophobic } \\
\text { Polyvinylidene } \\
\text { fluoride (PVDF) } \\
\text { membrane }\end{array}$ & Surface water & - & $\begin{array}{c}\text { Oxidants and bases } \\
400 \mathrm{ppm} \mathrm{NaClO} \\
0.1 \mathrm{M} \mathrm{NaOH}\end{array}$ & - & $\begin{array}{l}150 \\
60 \\
10\end{array}$ & [171] \\
\hline & $\begin{array}{l}\text { Cellulose } \\
\text { acetate (CA) } \\
\text { FO }\end{array}$ & $\begin{array}{c}200 \mathrm{mg} / \mathrm{L} \\
\text { alginate, } 50 \mathrm{mM} \\
\text { NaCl, and } 0.5 \\
\mathrm{mM} \mathrm{Ca}^{2+}\end{array}$ & $\begin{array}{c}\text { (DI) water } \\
\text { with } 28 \text { bars } \\
\quad(400 \text { psi) } \\
4 \mathrm{M} \mathrm{NaCl}\end{array}$ & $\begin{array}{l}21 \mathrm{~cm} / \mathrm{s}, 50 \mathrm{mM} \mathrm{NaCl} \\
\text { solution for } 15 \mathrm{~min}\end{array}$ & - & $\begin{array}{c}\mathrm{RO}= \\
70 \\
\mathrm{FO}= \\
100\end{array}$ & [103] \\
\hline $\begin{array}{l}\text { Combined } \\
\text { chemicals }\end{array}$ & $\begin{array}{l}\text { Polyethersul-fone } \\
\text { (PES) }\end{array}$ & $\begin{array}{l}\text { Synthetic } \\
\text { wastewater }\end{array}$ & - & $\begin{array}{l}\mathrm{NaClO}+\text { citric acid } \\
\text { recover membrane } \\
\text { permeability higher than } \\
\text { single-agent cleaning }\end{array}$ & $80 \%$ & $70-78$ & [172] \\
\hline
\end{tabular}


Table 3. Cont.

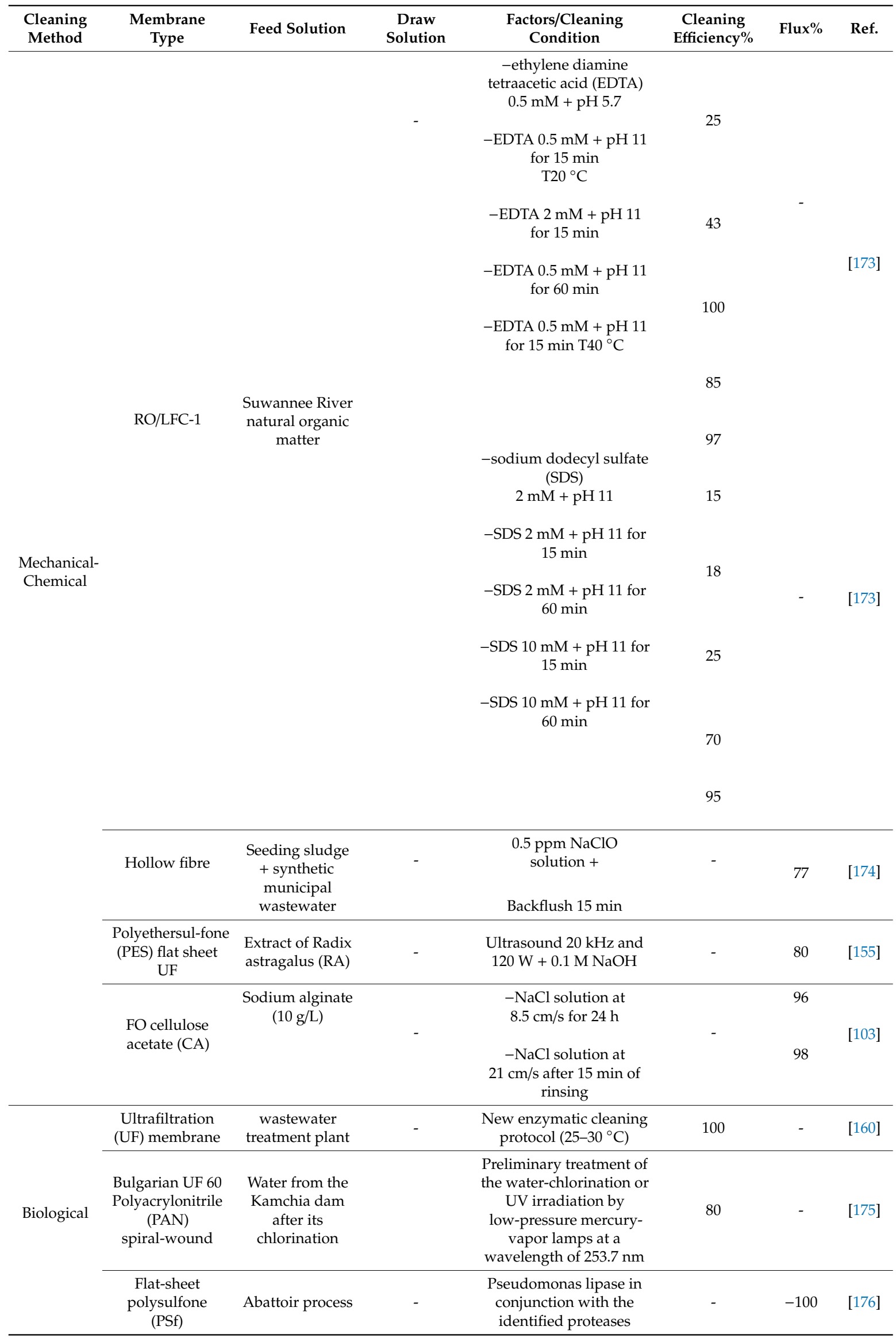




\section{Future Outlook and Conclusions}

Water and wastewater treatment using the FO process holds a significant promise for addressing the global water crisis. In general, the biggest challenge for $\mathrm{FO}$ commercialization originates from the financial feasibility. However, to maintain the FO process at commercial scale for wastewater treatment, there are critical challenges to overcome, such as fouling problems. An ideal FO membrane must exhibit high pure water flux with a low structural parameter value. One of the most complicated membrane fouling is organic fouling since it affects membrane performance and could result in irreversible fouling. Real-time monitoring of complex formation between organic foulants and membrane materials can help develop strategies to alleviate organic fouling. Several chemical and physical cleaning methods were developed to remove membrane fouling. However, a combination of chemical and physical cleaning methods is more efficient for membrane cleaning. New and innovative cleaning methods such as UV and ultrasound have not been thoroughly covered in the literature, and more experimental work should be done in future studies to investigate the efficiency and cost-effectiveness of non-conventional cleaning methods. Moreover, the research outcomes from various studies involving advanced membrane materials, draw solutions, pre-treatment, and post-treatment should be tested for real-time wastewater applications to facilitate the commercialisation of $\mathrm{FO}$ at industrial scale. Pilot-scale FO experiments need to be performed for a long-term operation to understand the formation of irreversible fouling in the FO process.

Author Contributions: Conceptualization, S.Y. and A.A.; methodology, S.Y. and A.A.; formal analysis, I.I., S.B. and D.K.; investigation, A.K.S., V.C.P. and A.A.; resources, A.A. and A.H.H.; writing-original draft preparation, S.Y.; writing-review and editing, A.A.; supervision, A.A.; project administration, A.A.; and funding acquisition, A.A. and A.H.H. All authors have read and agreed to the published version of the manuscript.

Funding: This research was funded by an NPRP grant (NPRP10-0117-170176) from the Qatar National Research Fund (a member of Qatar Foundation). This is the format recommended by the funding organization.

Acknowledgments: Candidate S.Y. would like to acknowledge scholarship support from the University of Technology Sydney under UTS President's Scholarship and International Research Scholarship (IRP). In addition, this publication was possible by an NPRP grant (NPRP10-0117-170176) from the Qatar National Research Fund (a member of Qatar Foundation). The findings achieved herein are solely the responsibility of the authors.

Conflicts of Interest: The authors declare no conflict of interest.

\section{References}

1. Chung, T.-S.; Luo, L.; Wan, C.F.; Cui, Y.; Amy, G. What is next for forward osmosis (FO) and pressure retarded osmosis (PRO). Sep. Purif. Technol. 2015, 156, 856-860. [CrossRef]

2. Sivakumar, M.; Yadav, S.; Hung, W.-S.; Lai, J.-Y. One-pot eco-friendly synthesis of edge-carboxylate graphene via dry ball milling for enhanced removal of acid and basic dyes from single or mixed aqueous solution. J. Cleaner Prod. 2020, 121498. [CrossRef]

3. Meena, N.K.; Nimbalkar, S.; Fatahi, B.; Yang, G. Effects of soil arching on behavior of pile-supported railway embankment: 2D FEM approach. Comput. Geotech. 2020, 123, 103601. [CrossRef]

4. Tang, W.; Zhang, Y.; Bai, J.; Li, J.; Wang, J.; Li, L.; Zhou, T.; Chen, S.; Rahim, M.; Zhou, B. Efficient denitrification and removal of natural organic matter, emerging pollutants simultaneously for RO concentrate based on photoelectrocatalytic radical reaction. Sep. Purif. Technol. 2020, 234, 116032. [CrossRef]

5. Li, C.; Song, C.; Tao, P.; Sun, M.; Pan, Z.; Wang, T.; Shao, M. Enhanced separation performance of coal-based carbon membranes coupled with an electric field for oily wastewater treatment. Sep. Purif. Technol. 2016, 168, 47-56. [CrossRef]

6. Jyothi, M.; Yadav, S.; Balakrishna, G. Effective recovery of acids from egg waste incorporated PSf membranes: A step towards sustainable development. J. Membr. Sci. 2018, 549, 227-235. [CrossRef]

7. Akamatsu, K.; Kagami, Y.; Nakao, S.-I. Effect of BSA and sodium alginate adsorption on decline of filtrate flux through polyethylene microfiltration membranes. J. Membr. Sci. 2020, 594, 117469. [CrossRef]

8. Bartels, C.; Wilf, M.; Casey, W.; Campbell, J. New generation of low fouling nanofiltration membranes. Desalination 2008, 221, 158-167. [CrossRef] 
9. Liu, C.; Liu, Y.; Guo, Y.; Wang, C.; Hu, Z.; Zhang, C. High-hydrophilic and salt rejecting PA-g/co-PVP RO membrane via bionic sand-fixing grass for pharmaceutical wastewater treatment. Chem. Eng. J. 2019, 357, 269-279. [CrossRef]

10. Racar, M.; Dolar, D.; Špehar, A.; Košutić, K. Application of UF/NF/RO membranes for treatment and reuse of rendering plant wastewater. Process Saf. Environ. Prot. 2017, 105, 386-392. [CrossRef]

11. Okamoto, Y.; Lienhard, J.H. How RO membrane permeability and other performance factors affect process cost and energy use: A review. Desalination 2019, 470, 114064. [CrossRef]

12. Yadav, S.; Saleem, H.; Ibrar, I.; Naji, O.; Hawari, A.A.; Alanezi, A.A.; Zaidi, S.J.; Altaee, A.; Zhou, J. Recent developments in forward osmosis membranes using carbon-based nanomaterials. Desalination 2020, 482, 114375. [CrossRef]

13. Shon, H.; Vigneswaran, S.; Kim, I.S.; Cho, J.; Ngo, H. Fouling of ultrafiltration membrane by effluent organic matter: A detailed characterization using different organic fractions in wastewater. J. Membr. Sci. 2006, 278, 232-238. [CrossRef]

14. Hancock, N.T.; Xu, P.; Heil, D.M.; Bellona, C.; Cath, T.Y. Comprehensive bench-and pilot-scale investigation of trace organic compounds rejection by forward osmosis. Environ. Sci. Technol. 2011, 45, 8483-8490. [CrossRef] [PubMed]

15. Kessler, J.; Moody, C. Drinking water from sea water by forward osmosis. Desalination 1976, 18, $297-306$. [CrossRef]

16. Tow, E.W.; Warsinger, D.M.; Trueworthy, A.M.; Swaminathan, J.; Thiel, G.P.; Zubair, S.M.; Myerson, A.S. Comparison of fouling propensity between reverse osmosis, forward osmosis, and membrane distillation. J. Membr. Sci. 2018, 556, 352-364. [CrossRef]

17. Bamaga, O.; Yokochi, A.; Zabara, B.; Babaqi, A. Hybrid FO/RO desalination system: Preliminary assessment of osmotic energy recovery and designs of new FO membrane module configurations. Desalination 2011, 268, 163-169. [CrossRef]

18. Lutchmiah, K.; Cornelissen, E.R.; Harmsen, D.J.; Post, J.W.; Lampi, K.; Ramaekers, H.; Rietveld, L.C.; Roest, K. Water recovery from sewage using forward osmosis. Water Sci. Technol. 2011, 64, 1443-1449. [CrossRef]

19. Iskander, S.M.; Zou, S.; Brazil, B.; Novak, J.T.; He, Z. Energy consumption by forward osmosis treatment of landfill leachate for water recovery. Waste Manag. 2017, 63, 284-291. [CrossRef]

20. Dong, Y.; Wang, Z.; Zhu, C.; Wang, Q.; Tang, J.; Wu, Z. A forward osmosis membrane system for the post-treatment of MBR-treated landfill leachate. J. Membr. Sci. 2014, 471, 192-200. [CrossRef]

21. Yang, S.; Gao, B.; Jang, A.; Kyong Shon, H.; Yue, Q. Municipal wastewater treatment by forward osmosis using seawater concentrate as draw solution. Chemosphere 2019, 237, 124485. [CrossRef] [PubMed]

22. Lutchmiah, K.; Verliefde, A.; Roest, K.; Rietveld, L.C.; Cornelissen, E. Forward osmosis for application in wastewater treatment: A review. Water Res. 2014, 58, 179-197. [CrossRef] [PubMed]

23. Phuntsho, S.; Shon, H.K.; Hong, S.; Lee, S.; Vigneswaran, S.; Kandasamy, J. Fertiliser drawn forward osmosis desalination: The concept, performance and limitations for fertigation. Rev. Environ. Sci. Bio/Technol. 2012, 11, 147-168. [CrossRef]

24. Korenak, J.; Basu, S.; Balakrishnan, M.; Hélix-Nielsen, C.; Petrinic, I. Forward osmosis in wastewater treatment processes. Acta Chim. Slov. 2017, 64, 83-94. [CrossRef]

25. Ibrar, I.; Naji, O.; Sharif, A.; Malekizadeh, A.; Alhawari, A.; Alanezi, A.A.; Altaee, A. A review of fouling mechanisms, control strategies and real-time fouling monitoring techniques in forward osmosis. Water 2019, 11, 695. [CrossRef]

26. Amy, G. Fundamental understanding of organic matter fouling of membranes. Desalination 2008, 231, 44-51. [CrossRef]

27. Cath, T.Y.; Childress, A.E.; Elimelech, M. Forward osmosis: Principles, applications, and recent developments. J. Membr. Sci. 2006, 281, 70-87. [CrossRef]

28. Wang, Y.-N.; Goh, K.; Li, X.; Setiawan, L.; Wang, R. Membranes and processes for forward osmosis-based desalination: Recent advances and future prospects. Desalination 2018, 434, 81-99. [CrossRef]

29. Nguyen, N.C.; Chen, S.-S.; Jain, S.; Nguyen, H.T.; Ray, S.S.; Ngo, H.H.; Guo, W.; Lam, N.T.; Duong, H.C. Exploration of an innovative draw solution for a forward osmosis-membrane distillation desalination process. Environ. Sci. Pollut. Res. 2018, 25, 5203-5211. [CrossRef] 
30. Bao, X.; Wu, Q.; Shi, W.; Wang, W.; Yu, H.; Zhu, Z.; Zhang, X.; Zhang, Z.; Zhang, R.; Cui, F. Polyamidoamine dendrimer grafted forward osmosis membrane with superior ammonia selectivity and robust antifouling capacity for domestic wastewater concentration. Water Res. 2019, 153, 1-10. [CrossRef]

31. Nagy, E. Basic Equations of Mass Transport Through a Membrane Layer; Elsevier: Amsterdam, The Netherlands, 2018.

32. Zhang, S.; Wang, K.Y.; Chung, T.-S.; Chen, H.; Jean, Y.; Amy, G. Well-constructed cellulose acetate membranes for forward osmosis: Minimized internal concentration polarization with an ultra-thin selective layer. J. Membr. Sci. 2010, 360, 522-535. [CrossRef]

33. Alshwairekh, A.M.; Alghafis, A.A.; Alwatban, A.M.; Alqsair, U.F.; Oztekin, A. The effects of membrane and channel corrugations in forward osmosis membrane modules-Numerical analyses. Desalination 2019, 460, 41-55. [CrossRef]

34. Li, J.-Y.; Ni, Z.-Y.; Zhou, Z.-Y.; Hu, Y.-X.; Xu, X.-H.; Cheng, L.-H. Membrane fouling of forward osmosis in dewatering of soluble algal products: Comparison of TFC and CTA membranes. J. Membr. Sci. 2018, 552, 213-221. [CrossRef]

35. Linares, R.V.; Li, Z.; Sarp, S.; Bucs, S.S.; Amy, G.; Vrouwenvelder, J.S. Forward osmosis niches in seawater desalination and wastewater reuse. Water Res. 2014, 66, 122-139. [CrossRef] [PubMed]

36. Ren, J.; McCutcheon, J.R. A new commercial thin film composite membrane for forward osmosis. Desalination 2014, 343, 187-193. [CrossRef]

37. Wang, Z.; Zheng, J.; Tang, J.; Wang, X.; Wu, Z. A pilot-scale forward osmosis membrane system for concentrating low-strength municipal wastewater: Performance and implications. Sci. Rep. 2016, 6, 21653. [CrossRef]

38. Park, M.J.; Phuntsho, S.; He, T.; Nisola, G.M.; Tijing, L.D.; Li, X.-M.; Chen, G.; Chung, W.-J.; Shon, H.K. Graphene oxide incorporated polysulfone substrate for the fabrication of flat-sheet thin-film composite forward osmosis membranes. J. Membr. Sci. 2015, 493, 496-507. [CrossRef]

39. Yu, Y.; Seo, S.; Kim, I.-C.; Lee, S. Nanoporous polyethersulfone (PES) membrane with enhanced flux applied in forward osmosis process. J. Membr. Sci. 2011, 375, 63-68. [CrossRef]

40. Zhang, X.; Shen, L.; Lang, W.-Z.; Wang, Y. Improved performance of thin-film composite membrane with PVDF/PFSA substrate for forward osmosis process. J. Membr. Sci. 2017, 535, 188-199. [CrossRef]

41. Qin, D.; Liu, Z.; Sun, D.D.; Song, X.; Bai, H. A new nanocomposite forward osmosis membrane custom-designed for treating shale gas wastewater. Sci. Rep. 2015, 5, 14530. [CrossRef]

42. Yadav, S.; Soontarapa, K.; Jyothi, M.; Padaki, M.; Balakrishna, R.G.; Lai, J.-Y. Supplementing multi-functional groups to polysulfone membranes using Azadirachta indica leaves powder for effective and highly selective acid recovery. J. Hazard. Mater. 2019, 369, 1-8. [CrossRef]

43. Shahabi, S.S.; Azizi, N.; Vatanpour, V. Synthesis and characterization of novel $\mathrm{g}-\mathrm{C}_{3} \mathrm{~N}_{4}$ modified thin film nanocomposite reverse osmosis membranes to enhance desalination performance and fouling resistance. Sep. Purif. Technol. 2019, 215, 430-440. [CrossRef]

44. Tian, M.; Wang, Y.-N.; Wang, R.; Fane, A.G. Synthesis and characterization of thin film nanocomposite forward osmosis membranes supported by silica nanoparticle incorporated nanofibrous substrate. Desalination 2017, 401, 142-150. [CrossRef]

45. Emadzadeh, D.; Lau, W.J.; Matsuura, T.; Rahbari-Sisakht, M.; Ismail, A.F. A novel thin film composite forward osmosis membrane prepared from $\mathrm{PSf}-\mathrm{TiO}_{2}$ nanocomposite substrate for water desalination. Chem. Eng. J. 2014, 237, 70-80. [CrossRef]

46. Ma, N.; Wei, J.; Liao, R.; Tang, C.Y. Zeolite-polyamide thin film nanocomposite membranes: Towards enhanced performance for forward osmosis. J. Membr. Sci. 2012, 405, 149-157. [CrossRef]

47. Zou, S.; Smith, E.D.; Lin, S.; Martin, S.M.; He, Z. Mitigation of bidirectional solute flux in forward osmosis via membrane surface coating of zwitterion functionalized carbon nanotubes. Environ. Int. 2019, 131, 104970. [CrossRef] [PubMed]

48. Yang, E.; Kim, C.-M.; Song, J.-h.; Ki, H.; Ham, M.-H.; Kim, I.S. Enhanced desalination performance of forward osmosis membranes based on reduced graphene oxide laminates coated with hydrophilic polydopamine. Carbon 2017, 117, 293-300. [CrossRef]

49. Wu, X.; Field, R.W.; Wu, J.J.; Zhang, K. Polyvinylpyrrolidone modified graphene oxide as a modifier for thin film composite forward osmosis membranes. J. Membr. Sci. 2017, 540, 251-260. [CrossRef] 
50. Saleem, H.; Trabzon, L.; Kilic, A.; Zaidi, S.J. Recent advances in nanofibrous membranes: Production and applications in water treatment and desalination. Desalination 2020, 478, 114178. [CrossRef]

51. Song, X.; Liu, Z.; Sun, D.D. Nano gives the answer: Breaking the bottleneck of internal concentration polarization with a nanofiber composite forward osmosis membrane for a high water production rate. Adv. Mater. 2011, 23, 3256-3260. [CrossRef]

52. Pardeshi, P.M.; Mungray, A.K.; Mungray, A.A. Polyvinyl chloride and layered double hydroxide composite as a novel substrate material for the forward osmosis membrane. Desalination 2017, 421, 149-159. [CrossRef]

53. Vu, M.T.; Ansari, A.J.; Hai, F.I.; Nghiem, L.D. Performance of a seawater-driven forward osmosis process for pre-concentrating digested sludge centrate: Organic enrichment and membrane fouling. Environ. Sci. Water Res. Technol. 2018, 4, 1047-1056. [CrossRef]

54. Vu, M.T.; Price, W.E.; He, T.; Zhang, X.; Nghiem, L.D. Seawater-driven forward osmosis for pre-concentrating nutrients in digested sludge centrate. J. Environ. Manag. 2019, 247, 135-139. [CrossRef] [PubMed]

55. Achilli, A.; Cath, T.Y.; Childress, A.E. Selection of inorganic-based draw solutions for forward osmosis applications. J. Membr. Sci. 2010, 364, 233-241. [CrossRef]

56. Johnson, D.J.; Suwaileh, W.A.; Mohammed, A.W.; Hilal, N. Osmotic's potential: An overview of draw solutes for forward osmosis. Desalination 2018, 434, 100-120. [CrossRef]

57. Zhang, H.; Li, J.; Cui, H.; Li, H.; Yang, F. Forward osmosis using electric-responsive polymer hydrogels as draw agents: Influence of freezing-thawing cycles, voltage, feed solutions on process performance. Chem. Eng. J. 2015, 259, 814-819. [CrossRef]

58. Phuntsho, S.; Shon, H.K.; Hong, S.; Lee, S.; Vigneswaran, S. A novel low energy fertilizer driven forward osmosis desalination for direct fertigation: Evaluating the performance of fertilizer draw solutions. J. Membr. Sci. 2011, 375, 172-181. [CrossRef]

59. Korenak, J.; Hélix-Nielsen, C.; Bukšek, H.; Petrinić, I. Efficiency and economic feasibility of forward osmosis in textile wastewater treatment. J. Clean. Prod. 2019, 210, 1483-1495. [CrossRef]

60. Zhao, S.; Zou, L.; Tang, C.Y.; Mulcahy, D. Recent developments in forward osmosis: Opportunities and challenges. J. Membr. Sci. 2012, 396, 1-21. [CrossRef]

61. Lee, S.; Kim, Y.; Park, J.; Shon, H.K.; Hong, S. Treatment of medical radioactive liquid waste using Forward Osmosis (FO) membrane process. J. Membr. Sci. 2018, 556, 238-247. [CrossRef]

62. Hawari, A.H.; Al-Qahoumi, A.; Ltaief, A.; Zaidi, S.; Altaee, A. Dilution of seawater using dewatered construction water in a hybrid forward osmosis system. J. Clean. Prod. 2018, 195, 365-373. [CrossRef]

63. Dutta, S.; Nath, K. Feasibility of forward osmosis using ultra low pressure RO membrane and Glauber salt as draw solute for wastewater treatment. J. Environ. Chem. Eng. 2018. [CrossRef]

64. Lee, W.J.; Goh, P.S.; Lau, W.J.; Ong, C.S.; Ismail, A.F. Antifouling zwitterion embedded forward osmosis thin film composite membrane for highly concentrated oily wastewater treatment. Sep. Purif. Technol. 2018. [CrossRef]

65. Liu, X.; Wu, J.; Wang, J. Removal of Cs(I) from simulated radioactive wastewater by three forward osmosis membranes. Chem. Eng. J. 2018, 344, 353-362. [CrossRef]

66. Liu, P.; Zhang, H.; Feng, Y.; Shen, C.; Yang, F. Integrating electrochemical oxidation into forward osmosis process for removal of trace antibiotics in wastewater. J. Hazard. Mater. 2015, 296, 248-255. [CrossRef] [PubMed]

67. Ang, W.L.; Mohammad, A.W.; Johnson, D.; Hilal, N. Forward osmosis research trends in desalination and wastewater treatment: A review of research trends over the past decade. J. Water Process Eng. 2019, 31, 100886. [CrossRef]

68. Aftab, B.; Ok, Y.S.; Cho, J.; Hur, J. Targeted removal of organic foulants in landfill leachate in forward osmosis system integrated with biochar/activated carbon treatment. Water Res. 2019, 160, 217-227. [CrossRef]

69. Lee, D.-J.; Hsieh, M.-H. Forward osmosis membrane processes for wastewater bioremediation: Research needs. Bioresour. Technol. 2019, 121795. [CrossRef]

70. Rudolph, G.; Virtanen, T.; Ferrando, M.; Güell, C.; Lipnizki, F.; Kallioinen, M. A review of in situ real-time monitoring techniques for membrane fouling in the biotechnology, biorefinery and food sectors. J. Membr. Sci. 2019, 117221. [CrossRef]

71. Mulder, M. Basic Principles of Membrane Technology; Springer Science \& Business Media: Cham, Switzerland, 2012. 
72. Baudequin, C.; Mai, Z.; Rakib, M.; Deguerry, I.; Severac, R.; Pabon, M.; Couallier, E. Removal of fluorinated surfactants by reverse osmosis-role of surfactants in membrane fouling. J. Membr. Sci. 2014, 458, 111-119. [CrossRef]

73. Sioutopoulos, D.; Goudoulas, T.; Kastrinakis, E.; Nychas, S.; Karabelas, A. Rheological and permeability characteristics of alginate fouling layers developing on reverse osmosis membranes during desalination. J. Membr. Sci. 2013, 434, 74-84. [CrossRef]

74. Braeken, L.; Van der Bruggen, B.; Vandecasteele, C. Flux Decline in Nanofiltration Due to Adsorption of Dissolved Organic Compounds: Model Prediction of Time Dependency. J. Phys. Chem. B 2006, 110, 2957-2962. [CrossRef]

75. Li, H.; Xia, H.; Mei, Y. Modeling organic fouling of reverse osmosis membrane: From adsorption to fouling layer formation. Desalination 2016, 386, 25-31. [CrossRef]

76. McCutcheon, J.R.; Elimelech, M. Influence of concentrative and dilutive internal concentration polarization on flux behavior in forward osmosis. J. Membr. Sci. 2006, 284, 237-247. [CrossRef]

77. Yip, N.Y.; Tiraferri, A.; Phillip, W.A.; Schiffman, J.D.; Hoover, L.A.; Kim, Y.C.; Elimelech, M. Thin-film composite pressure retarded osmosis membranes for sustainable power generation from salinity gradients. Environ. Sci. Technol. 2011, 45, 4360-4369. [CrossRef] [PubMed]

78. Her, N.; Amy, G.; McKnight, D.; Sohn, J.; Yoon, Y. Characterization of DOM as a function of MW by fluorescence EEM and HPLC-SEC using UVA, DOC, and fluorescence detection. Water Res. 2003, 37, 4295-4303. [CrossRef]

79. Frimmel, F.H.; Abbt-Braun, G.; Heumann, K.G.; Hock, B.; Lüdemann, H.-D.; Spiteller, M. Refractory Organic Substances in the Environment; John Wiley \& Sons: Hoboken, NJ, USA, 2008.

80. Van Geluwe, S.; Braeken, L.; Van der Bruggen, B. Ozone oxidation for the alleviation of membrane fouling by natural organic matter: A review. Water Res. 2011, 45, 3551-3570. [CrossRef]

81. McDonald, S.; Bishop, A.G.; Prenzler, P.D.; Robards, K. Analytical chemistry of freshwater humic substances. Anal. Chim. Acta 2004, 527, 105-124. [CrossRef]

82. Hessen, D.; Tranvik, L.J. Aquatic Humic Substances: Ecology and Biogeochemistry; Springer Science \& Business Media: Cham, Switzerland, 2013; Volume 133.

83. Suwaileh, W.; Pathak, N.; Shon, H.; Hilal, N. Forward osmosis membranes and processes: A comprehensive review of research trends and future outlook. Desalination 2020, 485, 114455. [CrossRef]

84. Gwak, G.; Kim, D.I.; Hong, S. New industrial application of forward osmosis (FO): Precious metal recovery from printed circuit board (PCB) plant wastewater. J. Membr. Sci. 2018, 552, 234-242. [CrossRef]

85. Coday, B.D.; Xu, P.; Beaudry, E.G.; Herron, J.; Lampi, K.; Hancock, N.T.; Cath, T.Y. The sweet spot of forward osmosis: Treatment of produced water, drilling wastewater, and other complex and difficult liquid streams. Desalination 2014, 333, 23-35. [CrossRef]

86. Kim, J.E.; Phuntsho, S.; Ali, S.M.; Choi, J.Y.; Shon, H.K. Forward osmosis membrane modular configurations for osmotic dilution of seawater by forward osmosis and reverse osmosis hybrid system. Water Res. 2018, 128, 183-192. [CrossRef]

87. Ali, S.M.; Kim, J.E.; Phuntsho, S.; Jang, A.; Choi, J.Y.; Shon, H.K. Forward osmosis system analysis for optimum design and operating conditions. Water Res. 2018, 145, 429-441. [CrossRef] [PubMed]

88. Ly, Q.V.; Hu, Y.; Li, J.; Cho, J.; Hur, J. Characteristics and influencing factors of organic fouling in forward osmosis operation for wastewater applications: A comprehensive review. Environ. Int. 2019, 129, 164-184. [CrossRef] [PubMed]

89. Boo, C.; Lee, S.; Elimelech, M.; Meng, Z.; Hong, S. Colloidal fouling in forward osmosis: Role of reverse salt diffusion. J. Membr. Sci. 2012, 390, 277-284. [CrossRef]

90. Mi, B.; Elimelech, M. Chemical and physical aspects of organic fouling of forward osmosis membranes. J. Membr. Sci. 2008, 320, 292-302. [CrossRef]

91. Gu, Y.; Wang, Y.-N.; Wei, J.; Tang, C.Y. Organic fouling of thin-film composite polyamide and cellulose triacetate forward osmosis membranes by oppositely charged macromolecules. Water Res. 2013, 47, 1867-1874. [CrossRef] [PubMed]

92. Motsa, M.M.; Mamba, B.B.; Verliefde, A.R. Forward osmosis membrane performance during simulated wastewater reclamation: Fouling mechanisms and fouling layer properties. J. Water Process Eng. 2018, 23, 109-118. [CrossRef] 
93. Filloux, E.; Gallard, H.; Croue, J.-P. Identification of effluent organic matter fractions responsible for low-pressure membrane fouling. Water Res. 2012, 46, 5531-5540. [CrossRef]

94. Aosai, D.; Saeki, D.; Iwatsuki, T.; Matsuyama, H. Efficient condensation of organic colloids in deep groundwater using surface-modified nanofiltration membranes under optimized hydrodynamic conditions. Colloids Surf. A Physicochem. Eng. Asp. 2016, 495, 68-78. [CrossRef]

95. Stevenson, F.J. Humus Chemistry: Genesis, Composition, Reactions; John Wiley \& Sons: Hoboken, NJ, USA, 1994.

96. Wang, L.; Zhang, W.; Chu, H.; Dong, B. Forward osmosis filtration for removal of organic foulants: Effects of combined tannic and alginic acids. Water Res. 2016, 91, 251-263. [CrossRef]

97. Hong, S.; Elimelech, M. Chemical and physical aspects of natural organic matter (NOM) fouling of nanofiltration membranes. J. Membr. Sci. 1997, 132, 159-181. [CrossRef]

98. Seidel, A.; Elimelech, M. Coupling between chemical and physical interactions in natural organic matter (NOM) fouling of nanofiltration membranes: Implications for fouling control. J. Membr. Sci. 2002, 203, 245-255. [CrossRef]

99. Lee, S.; Boo, C.; Elimelech, M.; Hong, S. Comparison of fouling behavior in forward osmosis (FO) and reverse osmosis (RO). J. Membr. Sci. 2010, 365, 34-39. [CrossRef]

100. Abdikheibari, S.; Dumée, L.F.; Jegatheesan, V.; Mustafa, Z.; Le-Clech, P.; Lei, W.; Baskaran, K. Natural organic matter removal and fouling resistance properties of a boron nitride nanosheet-functionalized thin film nanocomposite membrane and its impact on permeate chlorine demand. J. Water Process Eng. 2020, 34, 101160. [CrossRef]

101. Xu, Y.; Liu, P.; Xu, S.; Koroleva, M.; Zhang, S.; Si, S.; Jin, Z.G. Tannic acid as a plant-derived polyphenol exerts vasoprotection via enhancing KLF2 expression in endothelial cells. Sci. Rep. 2017, 7, 1-9. [CrossRef]

102. Parida, V.; Ng, H.Y. Forward osmosis organic fouling: Effects of organic loading, calcium and membrane orientation. Desalination 2013, 312, 88-98. [CrossRef]

103. Mi, B.; Elimelech, M. Organic fouling of forward osmosis membranes: Fouling reversibility and cleaning without chemical reagents. J. Membr. Sci. 2010, 348, 337-345. [CrossRef]

104. Mazlan, N.M.; Marchetti, P.; Maples, H.; Gu, B.; Karan, S.; Bismarck, A.; Livingston, A.G. Organic fouling behaviour of structurally and chemically different forward osmosis membranes-a study of cellulose triacetate and thin film composite membranes. J. Membr. Sci. 2016, 520, 247-261. [CrossRef]

105. Nguyen, T.-T.; Lee, C.; Field, R.W.; Kim, I.S. Insight into organic fouling behavior in polyamide thin-film composite forward osmosis membrane: Critical flux and its impact on the economics of water reclamation. J. Membr. Sci. 2020, 606, 118118. [CrossRef]

106. She, Q.; Wong, Y.K.W.; Zhao, S.; Tang, C.Y. Organic fouling in pressure retarded osmosis: Experiments, mechanisms and implications. J. Membr. Sci. 2013, 428, 181-189. [CrossRef]

107. Zhang, W.; Wang, L.; Dong, B. Effects of tannic acid on membrane fouling and membrane cleaning in forward osmosis. Water Sci. Technol. 2017, 76, 3160-3170. [CrossRef]

108. Li, Z.; Jiang, L.; Tang, C. Investigation on removing recalcitrant toxic organic polluters in coking wastewater by forward osmosis. Chin. J. Chem. Eng. 2020, 28, 122-135. [CrossRef]

109. Wang, S.; Amornwittawat, N.; Banatlao, J.; Chung, M.; Kao, Y.; Wen, X. Hofmeister effects of common monovalent salts on the beetle antifreeze protein activity. J. Phys. Chem. B 2009, 113, 13891-13894. [CrossRef] [PubMed]

110. Law, C.M.; Li, X.-Y.; Li, Q. The combined colloid-organic fouling on nanofiltration membrane for wastewater treatment and reuse. Sep. Sci. Technol. 2010, 45, 935-940. [CrossRef]

111. Zazouli, M.A.; Nasseri, S.; Ulbricht, M. Fouling effects of humic and alginic acids in nanofiltration and influence of solution composition. Desalination 2010, 250, 688-692. [CrossRef]

112. Balkenov, A.; Anuarbek, A.; Satayeva, A.; Kim, J.; Inglezakis, V.; Arkhangelsky, E. Complex organic fouling and effect of silver nanoparticles on aquaporin forward osmosis membranes. J. Water Process Eng. 2020, 34, 101177. [CrossRef]

113. Kim, Y.; Elimelech, M.; Shon, H.K.; Hong, S. Combined organic and colloidal fouling in forward osmosis: Fouling reversibility and the role of applied pressure. J. Membr. Sci. 2014, 460, 206-212. [CrossRef]

114. Pramanik, B.K.; Shu, L.; Jegatheesan, V.; Bhuiyan, M.A. Effect of the coagulation/persulfate pre-treatment to mitigate organic fouling in the forward osmosis of municipal wastewater treatment. J. Environ. Manag. 2019, 249, 109394. [CrossRef] 
115. Aftab, B.; Cho, J.; Hur, J. Intermittent osmotic relaxation: A strategy for organic fouling mitigation in a forward osmosis system treating landfill leachate. Desalination 2020, 482, 114406. [CrossRef]

116. Pramanik, B.K.; Hai, F.I.; Roddick, F.A. Ultraviolet/persulfate pre-treatment for organic fouling mitigation of forward osmosis membrane: Possible application in nutrient mining from dairy wastewater. Sep. Purif. Technol. 2019, 217, 215-220. [CrossRef]

117. Im, S.-J.; Jeong, G.; Jeong, S.; Cho, J.; Jang, A. Fouling and transport of organic matter in cellulose triacetate forward-osmosis membrane for wastewater reuse and seawater desalination. Chem. Eng. J. 2020, 384, 123341. [CrossRef]

118. Sun, F.; Lu, D.; Ho, J.S.; Chong, T.H.; Zhou, Y. Mitigation of membrane fouling in a seawater-driven forward osmosis system for waste activated sludge thickening. J. Clean. Prod. 2019, 241, 118373. [CrossRef]

119. Ye, J.; Zhou, Q.; Zhang, X.; Hu, Q. Microalgal dewatering using a polyamide thin film composite forward osmosis membrane and fouling mitigation. Algal Res. 2018, 31, 421-429. [CrossRef]

120. Akther, N.; Yuan, Z.; Chen, Y.; Lim, S.; Phuntsho, S.; Ghaffour, N.; Matsuyama, H.; Shon, H. Influence of graphene oxide lateral size on the properties and performances of forward osmosis membrane. Desalination 2020, 484, 114421. [CrossRef]

121. Ibrar, I.; Altaee, A.; Zhou, J.L.; Naji, O.; Khanafer, D. Challenges and potentials of forward osmosis process in the treatment of wastewater. Crit. Rev. Environ. Sci. Technol. 2019, 1-45. [CrossRef]

122. Emadzadeh, D.; Lau, W.; Matsuura, T.; Hilal, N.; Ismail, A. The potential of thin film nanocomposite membrane in reducing organic fouling in forward osmosis process. Desalination 2014, 348, 82-88. [CrossRef]

123. Liu, Y.; Mi, B. Effects of organic macromolecular conditioning on gypsum scaling of forward osmosis membranes. J. Membr. Sci. 2014, 450, 153-161. [CrossRef]

124. Carroll, T.; King, S.; Gray, S.; Bolto, B.A.; Booker, N. The fouling of microfiltration membranes by NOM after coagulation treatment. Water Res. 2000, 34, 2861-2868. [CrossRef]

125. Blume, T.; Neis, U. Improved wastewater disinfection by ultrasonic pre-treatment. Ultrason. Sonochemistry 2004, 11, 333-336. [CrossRef]

126. Suarez, S.; Lema, J.M.; Omil, F. Pre-treatment of hospital wastewater by coagulation-flocculation and flotation. Bioresour. Technol. 2009, 100, 2138-2146. [CrossRef]

127. Hancock, N.T.; Black, N.D.; Cath, T.Y. A comparative life cycle assessment of hybrid osmotic dilution desalination and established seawater desalination and wastewater reclamation processes. Water Res. 2012, 46, 1145-1154. [CrossRef]

128. Engelhardt, S.; Vogel, J.; Duirk, S.E.; Moore, F.B.; Barton, H.A. Assessment of urea hydrolysis as a pretreatment strategy to improve total nitrogen rejection from urine using aquaporin-based membranes in forward osmosis. J. Water Process Eng. 2020, 34, 101135. [CrossRef]

129. Al Hawli, B.; Benamor, A.; Hawari, A.A. A hybrid electro-coagulation/forward osmosis system for treatment of produced water. Chem. Eng. Process. Process Intensif. 2019, 143, 107621. [CrossRef]

130. Jamil, S.; Loganathan, P.; Kazner, C.; Vigneswaran, S. Forward osmosis treatment for volume minimisation of reverse osmosis concentrate from a water reclamation plant and removal of organic micropollutants. Desalination 2015, 372, 32-38. [CrossRef]

131. Gao, W.; Liang, H.; Ma, J.; Han, M.; Chen, Z.-L.; Han, Z.-S.; Li, G.-B. Membrane fouling control in ultrafiltration technology for drinking water production: A review. Desalination 2011, 272, 1-8. [CrossRef]

132. Le-Clech, P.; Chen, V.; Fane, T.A. Fouling in membrane bioreactors used in wastewater treatment. J. Membr. Sci. 2006, 284, 17-53. [CrossRef]

133. Ndinisa, N.; Fane, A.; Wiley, D.; Fletcher, D. Fouling control in a submerged flat sheet membrane system: Part II-Two-phase flow characterization and CFD simulations. Sep. Sci. Technol. 2006, 41, 1411-1445. [CrossRef]

134. Arkhangelsky, E.; Wicaksana, F.; Chou, S.; Al-Rabiah, A.A.; Al-Zahrani, S.M.; Wang, R. Effects of scaling and cleaning on the performance of forward osmosis hollow fiber membranes. J. Membr. Sci. 2012, 415, 101-108. [CrossRef]

135. Yip, N.Y.; Elimelech, M. Influence of natural organic matter fouling and osmotic backwash on pressure retarded osmosis energy production from natural salinity gradients. Environ. Sci. Technol. 2013, 47, 12607-12616. [CrossRef]

136. Holloway, R.W.; Childress, A.E.; Dennett, K.E.; Cath, T.Y. Forward osmosis for concentration of anaerobic digester centrate. Water Res. 2007, 41, 4005-4014. [CrossRef] 
137. Hickenbottom, K.L.; Hancock, N.T.; Hutchings, N.R.; Appleton, E.W.; Beaudry, E.G.; Xu, P.; Cath, T.Y. Forward osmosis treatment of drilling mud and fracturing wastewater from oil and gas operations. Desalination 2013, 312, 60-66. [CrossRef]

138. Lay, W.C.; Zhang, J.; Tang, C.; Wang, R.; Liu, Y.; Fane, A.G. Factors affecting flux performance of forward osmosis systems. J. Membr. Sci. 2012, 394, 151-168. [CrossRef]

139. Achilli, A.; Cath, T.Y.; Marchand, E.A.; Childress, A.E. The forward osmosis membrane bioreactor: A low fouling alternative to MBR processes. Desalination 2009, 239, 10-21. [CrossRef]

140. Hancock, N.T.; Xu, P.; Roby, M.J.; Gomez, J.D.; Cath, T.Y. Towards direct potable reuse with forward osmosis: Technical assessment of long-term process performance at the pilot scale. J. Membr. Sci. 2013, 445, 34-46. [CrossRef]

141. Linares, R.V.; Li, Z.; Abu-Ghdaib, M.; Wei, C.-H.; Amy, G.; Vrouwenvelder, J.S. Water harvesting from municipal wastewater via osmotic gradient: An evaluation of process performance. J. Membr. Sci. 2013, 447, 50-56. [CrossRef]

142. Tragardh, G. Membrane cleaning. Desalination 1989, 71, 325-335. [CrossRef]

143. Maartens, A.; Jacobs, E.; Swart, P. UF of pulp and paper effluent: Membrane fouling-prevention and cleaning. J. Membr. Sci. 2002, 209, 81-92. [CrossRef]

144. Zondervan, E.; Roffel, B. Evaluation of different cleaning agents used for cleaning ultra filtration membranes fouled by surface water. J. Membr. Sci. 2007, 304, 40-49. [CrossRef]

145. Weis, A.; Bird, M.R.; Nyström, M. The chemical cleaning of polymeric UF membranes fouled with spent sulphite liquor over multiple operational cycles. J. Membr. Sci. 2003, 216, 67-79. [CrossRef]

146. Valladares Linares, R.; Li, Z.; Yangali-Quintanilla, V.; Li, Q.; Amy, G. Cleaning protocol for a FO membrane fouled in wastewater reuse. Desalin. Water Treat. 2013, 51, 4821-4824. [CrossRef]

147. Yoon, H.; Baek, Y.; Yu, J.; Yoon, J. Biofouling occurrence process and its control in the forward osmosis. Desalination 2013, 325, 30-36. [CrossRef]

148. Linares, R.V.; Yangali-Quintanilla, V.; Li, Z.; Amy, G. NOM and TEP fouling of a forward osmosis (FO) membrane: Foulant identification and cleaning. J. Membr. Sci. 2012, 421, 217-224. [CrossRef]

149. Wang, Z.; Tang, J.; Zhu, C.; Dong, Y.; Wang, Q.; Wu, Z. Chemical cleaning protocols for thin film composite (TFC) polyamide forward osmosis membranes used for municipal wastewater treatment. J. Membr. Sci. 2015, 475, 184-192. [CrossRef]

150. Qin, J.-J.; Liberman, B.; A Kekre, K.; Gossan, A. Direct osmosis for reverse osmosis fouling control: Principles, applications and recent developments. Open Chem. Eng. J. 2009, 3. [CrossRef]

151. Ang, W.S.; Yip, N.Y.; Tiraferri, A.; Elimelech, M. Chemical cleaning of RO membranes fouled by wastewater effluent: Achieving higher efficiency with dual-step cleaning. J. Membr. Sci. 2011, 382, 100-106. [CrossRef]

152. Ang, W.S.; Tiraferri, A.; Chen, K.L.; Elimelech, M. Fouling and cleaning of RO membranes fouled by mixtures of organic foulants simulating wastewater effluent. J. Membr. Sci. 2011, 376, 196-206. [CrossRef]

153. Buzatu, P.; Zsirai, T.; Aerts, P.; Judd, S. Permeability and clogging in an immersed hollow fibre membrane bioreactor. J. Membr. Sci. 2012, 421, 342-348. [CrossRef]

154. Wang, Z.; Ma, J.; Tang, C.Y.; Kimura, K.; Wang, Q.; Han, X. Membrane cleaning in membrane bioreactors: A review. J. Membr. Sci. 2014, 468, 276-307. [CrossRef]

155. Cai, M.; Wang, S.; Zheng, Y.; Liang, H. Effects of ultrasound on ultrafiltration of Radix astragalus extract and cleaning of fouled membrane. Sep. Purif. Technol. 2009, 68, 351-356. [CrossRef]

156. Maskooki, A.; Mortazavi, S.A.; Maskooki, A. Cleaning of spiralwound ultrafiltration membranes using ultrasound and alkaline solution of EDTA. Desalination 2010, 264, 63-69. [CrossRef]

157. Kwon, B.; Park, N.; Cho, J. Effect of algae on fouling and efficiency of UF membranes. Desalination 2005, 179, 203-214. [CrossRef]

158. Munoz-Aguado, M.; Wiley, D.; Fane, A. Enzymatic and detergent cleaning of a polysulfone ultrafiltration membrane fouled with BSA and whey. J. Membr. Sci. 1996, 117, 175-187. [CrossRef]

159. Lin, H.; Peng, W.; Zhang, M.; Chen, J.; Hong, H.; Zhang, Y. A review on anaerobic membrane bioreactors: Applications, membrane fouling and future perspectives. Desalination 2013, 314, 169-188. [CrossRef]

160. Te Poele, S.; Van der Graaf, J. Enzymatic cleaning in ultrafiltration of wastewater treatment plant effluent. Desalination 2005, 179, 73-81. [CrossRef]

161. She, Q.; Wang, R.; Fane, A.G.; Tang, C.Y. Membrane fouling in osmotically driven membrane processes: A review. J. Membr. Sci. 2016, 499, 201-233. [CrossRef] 
162. Judd, S. The MBR Book: Principles and Applications of Membrane Bioreactors for Water and Wastewater Treatment; Elsevier: Amsterdam, The Netherlands, 2010.

163. Liang, H.; Gong, W.; Chen, J.; Li, G. Cleaning of fouled ultrafiltration (UF) membrane by algae during reservoir water treatment. Desalination 2008, 220, 267-272. [CrossRef]

164. Al-Amoudi, A.; Lovitt, R.W. Fouling strategies and the cleaning system of NF membranes and factors affecting cleaning efficiency. J. Membr. Sci. 2007, 303, 4-28. [CrossRef]

165. Porcelli, N.; Judd, S. Chemical cleaning of potable water membranes: A review. Sep. Purif. Technol. 2010, 71, 137-143. [CrossRef]

166. Carey, F.A.; Sundberg, R.J. Advanced Organic Chemistry: Part A: Structure and Mechanisms; Springer Science \& Business Media: Cham, Switzerland, 2007.

167. Bartlett, M.; Bird, M.; Howell, J. An experimental study for the development of a qualitative membrane cleaning model. J. Membr. Sci. 1995, 105, 147-157. [CrossRef]

168. Ang, W.S.; Lee, S.; Elimelech, M. Chemical and physical aspects of cleaning of organic-fouled reverse osmosis membranes. J. Membr. Sci. 2006, 272, 198-210. [CrossRef]

169. Li, T.; Law, A.W.-K.; Cetin, M.; Fane, A. Fouling control of submerged hollow fibre membranes by vibrations. J. Membr. Sci. 2013, 427, 230-239. [CrossRef]

170. Chen, D.; Weavers, L.K.; Walker, H.W. Ultrasonic control of ceramic membrane fouling by particles: Effect of ultrasonic factors. Ultrason. Sonochemistry 2006, 13, 379-387. [CrossRef] [PubMed]

171. Liu, C.; Caothien, S.; Hayes, J.; Caothuy, T.; Otoyo, T.; Ogawa, T. Membrane chemical cleaning: From art to science. Pall Corp. Port Wash. NY 2001, 11050.

172. Wang, Z.; Zhang, Q.; Ma, Y.; Yang, L.; Lyu, Y.; Zhao, S. Influence of various operating conditions on cleaning efficiency in sequencing batch reactor (SBR) activated sludge process. Part III: Chemical cleaning. Desalination 2013, 325, 122-131. [CrossRef]

173. Ang, W.S. Optimization of Chemical Cleaning of Organic-Fouled Reverse Osmosis Membranes; Yale University: New Haven, CT, USA, 2008.

174. Wang, Z.; Meng, F.; He, X.; Zhou, Z.; Huang, L.-N.; Liang, S. Optimisation and performance of NaClO-assisted maintenance cleaning for fouling control in membrane bioreactors. Water Res. 2014, 53, 1-11. [CrossRef]

175. Pavlova, S. Study on the cleaning of new ultrafiltration spiral-woundmodules to prevent membrane fouling (including biological fouling). Desalination 2005, 172, 267-270. [CrossRef]

176. Allie, Z.; Jacobs, E.; Maartens, A.; Swart, P. Enzymatic cleaning of ultrafiltration membranes fouled by abattoir effluent. J. Membr. Sci. 2003, 218, 107-116. [CrossRef] 